Article

\title{
Purpurogemutantin and Purpurogemutantidin, New Drimenyl Cyclohexenone Derivatives Produced by a Mutant Obtained by Diethyl Sulfate Mutagenesis of a Marine-Derived Penicillium purpurogenum G59
}

\section{Shi-Ming Fang ${ }^{1,2}$, Cheng-Bin Cui ${ }^{1,2, *}$, Chang-Wei Li ${ }^{1}$, Chang-Jing Wu ${ }^{1}$, Zhi-Jun Zhang ${ }^{1}$, $\mathrm{Li} \mathrm{Li}^{3}$, Xiao-Jun Huang ${ }^{4}$ and Wen-Cai Ye ${ }^{4}$}

1 Beijing Institute of Pharmacology and Toxicology, Beijing 100850, China; E-Mails: fang_shiming@163.com (S.-M.F.); sdrlcw@sohu.com (C.-W.L.); wucj2009@163.com (C.-J.W.); zzjcust@sina.com (Z.-J.Z.)

2 Key Laboratory of Structure-Based Drug Design \& Discovery of Ministry of Education, School of Traditional Chinese Materia Medica, Shenyang Pharmaceutical University, Shenyang 110016, China

3 State Key Laboratory of Bioactive Substance and Function of Natural Medicines, Institute of Materia Medica, Chinese Academy of Medical Sciences and Peking Union Medical College, Beijing 100050, China; E-Mail: annaleelin@imm.ac.cn

4 Institute of Traditional Chinese Medicine \& Natural Products, Jinan University, Guangzhou 510632, China; E-Mails: zhyxiaohuang@163.com (X.-J.H.); chywc@yahoo.com.cn (W.-C.Y.)

* Author to whom correspondence should be addressed; E-Mail: cuicb@sohu.com or cuicb@126.com; Tel./Fax: +86-10-6821-1656.

Received: 9 March 2012; in revised form: 24 May 2012 / Accepted: 24 May 2012 /

Published: 4 June 2012

\begin{abstract}
Two new drimenyl cyclohexenone derivatives, named purpurogemutantin (1) and purpurogemutantidin (2), and the known macrophorin A (3) were isolated from a bioactive mutant BD-1-6 obtained by random diethyl sulfate (DES) mutagenesis of a marine-derived Penicillium purpurogenum G59. Structures and absolute configurations of $\mathbf{1}$ and $\mathbf{2}$ were determined by extensive spectroscopic methods, especially 2D NMR and electronic circular dichroism (ECD) analysis. Possible biosynthetic pathways for $\mathbf{1}-\mathbf{3}$ were also proposed and discussed. Compounds $\mathbf{1}$ and $\mathbf{2}$ significantly inhibited human cancer K562, HL-60, HeLa, BGC-823 and MCF-7 cells, and compound 3 also inhibited the K562 and HL-60 cells. Both bioassay and chemical analysis (HPLC, LC-ESIMS) demonstrated that the parent strain G59 did not produce 1-3, and that DES-induced mutation(s) in the
\end{abstract}


mutant BD-1-6 activated some silent biosynthetic pathways in the parent strain G59, including one set for $\mathbf{1}-\mathbf{3}$ production.

Keywords: purpurogemutantin; purpurogemutantidin; sesquiterpene; meroterpenoid; structure determination; antitumor activity; Penicillium purpurogenum; marine-derived fungus; DES mutagenesis

\section{Introduction}

Meroterpenoids, generally occurring in nature, display a huge range of structural diversity with a broad spectrum of important biological activities [1]. Drimane or 4,9-friedodrimane meroterpenoids with a quinone or hydroquinone moiety were frequently isolated from marine sponges [2-8] and algae [9-11]. The same class of compounds having a regular drimane skeleton were also often isolated from both plant-associated [12-15] and marine-derived [16] fungi. Among them, $(-)$-taurinin [12,13,17], (-)-F-12509A [14,18], (+)-hyatellaquinone [11,19], (+)-zonarol [10,20,21] and $(+)$-zonarone [10,21,22] were synthesized [17-22] to determine their absolute configurations. Relative stereochemistry of the drimenyl unit in these compounds is the same as that in albicanol [23], a simple drimene alcohol with a hydroxymethyl group in the drimene skeleton. However, the absolute configuration of the drimenyl residue is opposite in these compounds, indicating the occurrence of both drimenyl enantiomers in nature. Cyclohexenone derivatives structurally closely related to these drimene quinones are rare in nature, macrophorins $\mathrm{A}-\mathrm{C}$ [24,25], macrophorin $\mathrm{D}$ [26,27], 4'-oxomacrophorin A [27], 4'-oxomacrophorin D [27], macrophorins E-G [28], 2',3'-epoxy-13hydroxy-4'-oxomacrophorin A [29], epoxyphomalins A and B [30], and penicilliumin A [31] being examples isolated from plant-associated [24-28] and marine-derived [29-31] fungi. Some of these exhibited antimicrobial [24,25,28,29], self-inhibitory [26], immunosuppressive [27], or in vitro antitumor [30,31] activities.

Several Penicillium purpurogenum strains are known to produce bioactive metabolites with novel structures [32-36], including antitumor metabolites [32]. However, Penicillium purpurogenum G59, a marine-derived wild-type strain isolated by our group, was originally not able to produce antitumor metabolites with activity in the MTT assay using K562 cells [37]. It has been well recognized that the main biosynthetic pathways in most microbial strains are silent and thus unable to produce secondary metabolites under usual laboratory culture conditions [38]. Thus, various approaches were developed to awake the silent biosynthetic pathways to access cryptic secondary metabolites. Among them, the one strain many compounds (OSMAC) strategy [39], ribosome engineering [40,41], and chemical epigenetics method $[42,43]$ could be simply applied by natural product chemists owing to their practical experimental procedures. We have also reported a new and simple approach to activate the dormant secondary metabolite production by introducing gentamicin resistance in P. purpurogenum G59 [44]. Using this method, we obtained nine antitumor mutants from strain G59 [44], and several antitumor secondary metabolites newly produced by two bioactive mutants were also explored previously [44,45]. Later, we attempted to activate the silent secondary metabolite production in strain G59 by random diethyl sulfate (DES) mutagenesis and succeeded in obtaining an antitumor mutant BD-1-6. 
To examine the effect of DES-induced mutation on the secondary metabolite production, we carried out chemical investigation of antitumor secondary metabolites of the mutant BD-1-6. Bioassay-guided fractionation of the BD-1-6 culture extract resulted in the isolation of three antitumor metabolites 1-3 (Figure 1), all being newly produced by the mutant BD-1-6 compared to its parent strain G59. Structures of two new compounds, named purpurogemutantin (1) and purpurogemutantidin (2), were elucidated by various spectroscopic methods and their absolute configurations were determined on the basis of CD and ECD data. The isolation, structure elucidation, cytotoxicity assay, and HPLC and LC-ESIMS analysis for $\mathbf{1}-\mathbf{3}$ are reported in detail in this paper.

Figure 1. Structures of 1-3 from the mutant strain Penicillium purpurogenum BD-1-6.
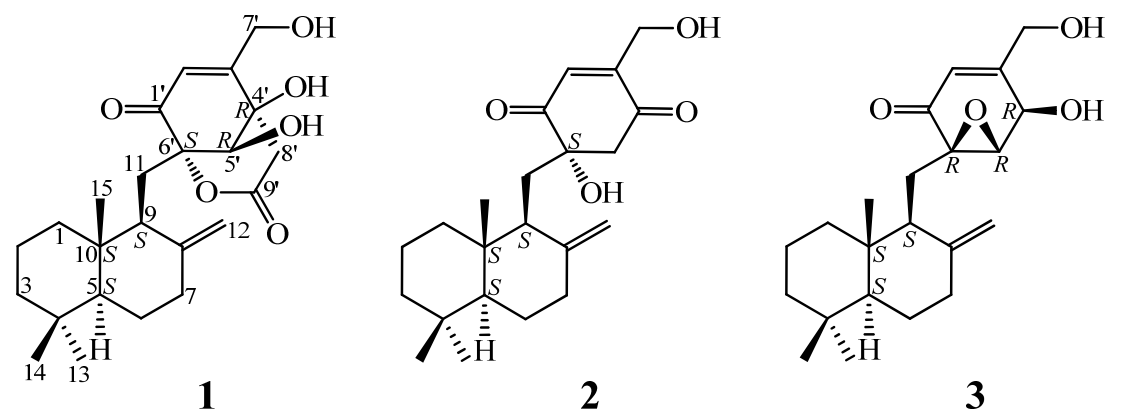

\section{Results and Discussion}

Fermentation and extraction of the mutant BD-1-6 provided an ethyl acetate extract showing cytotoxicity on $\mathrm{K} 562$ cells with an inhibition rate of $58.6 \%$ at $100 \mu \mathrm{g} / \mathrm{mL}$. Bioassay-guided column chromatography of the extract delivered active fractions, which were then subjected to a semi-preparative HPLC separation to afford bioactive metabolites 1-3.

Compound 3, a pale-colored solid, $[\alpha]_{\mathrm{D}}^{20}+25.7$ (c 1.0, MeOH), afforded a molecular weight of 360 Dalton by positive and negative ESI-MSs and was identified as macrophorin A [24] according to the physicochemical and spectroscopic data. Full ${ }^{1} \mathrm{H}$ NMR data of $\mathbf{3}$ are reported for the first time.

\subsection{Structure Determination of $\mathbf{1}$ and $\mathbf{2}$}

Purpurogemutantin (1) was obtained as a white crystalline powder from $\mathrm{MeOH}$ solution, $\mathrm{mp}$ $122-123{ }^{\circ} \mathrm{C},[\alpha]_{\mathrm{D}}^{20}+21.0(c \quad 1.0, \mathrm{MeOH})$, and its molecular formula $\mathrm{C}_{24} \mathrm{H}_{34} \mathrm{O}_{6}$ was determined by HRESIMS $\left(m / z 419.2431[\mathrm{M}+\mathrm{H}]^{+} ; \Delta=+0.3 \mathrm{mmu}\right)$. Its UV $\left(\lambda_{\max } 234 \mathrm{~nm}, \log \varepsilon 3.87\right)$ and IR $\left(v_{\max }\right.$ 1694, $889 \mathrm{~cm}^{-1}$ ) absorptions revealed an $\alpha, \beta$-unsaturated ketone chromophore [24] in 1. The IR spectrum of 1 further indicated the presence of hydroxyl $\left(3405 \mathrm{~cm}^{-1}\right)$ and ester carbonyl $\left(1733 \mathrm{~cm}^{-1}\right)$ groups. The ${ }^{1} \mathrm{H}$ NMR spectrum of $\mathbf{1}$ in acetone- $d_{6}$ showed signals due to three tert-methyl groups, three olefinic and three exchangeable protons together with several methine and methylene proton signals (Table 1). The ${ }^{13} \mathrm{C}$ NMR spectrum in acetone- $d_{6}$, analyzed by DEPT, revealed the presence of a conjugated ketone carbonyl, an ester carbonyl, two $\mathrm{sp}^{2}$ and four $\mathrm{sp}^{3}$ quaternary carbons, one $\mathrm{sp}^{2}$ and three $\mathrm{sp}^{3}$ methine, one $\mathrm{sp}^{2}$ and eight $\mathrm{sp}^{3}$ methylene, and three methyl groups in 1 (Table 1). The ESIMS, HRESIMS, UV, IR, ${ }^{1} \mathrm{H}$ and ${ }^{13} \mathrm{C}$ NMR, DEPT, ${ }^{1} \mathrm{H}-{ }^{1} \mathrm{H}$ COSY, HMQC, HMBC, and NOESY spectra of $\mathbf{1}$ are given as supporting information in Supplementary Data S1. 
Table 1. $400 \mathrm{MHz}{ }^{1} \mathrm{H}$ and $100 \mathrm{MHz}{ }^{13} \mathrm{C}$ NMR data of 1 in acetone- $d_{6}{ }^{a}$.

\begin{tabular}{|c|c|c|c|c|c|}
\hline Position & $\delta_{C}^{b, c}$ & $\delta_{H}^{b}(J$ in Hz $)$ & COSY $^{d}$ & NOE $^{\mathrm{e}}$ & HMBC $^{\text {f }}$ \\
\hline \multirow[t]{2}{*}{1} & $39.3 \mathrm{t}$ & $\mathrm{H} a 1.12 \operatorname{td}(13.7,3.4)$ & $\mathrm{He}-1, \mathrm{H}_{2}-2$ & $\mathrm{H} e-1, \mathrm{H} e-2, \mathrm{H} a-2^{\mathrm{g}}, \mathrm{H} a-7, \mathrm{H}-9$ & \\
\hline & & He 1.723 br d (13.7) & $\mathrm{H} a-1, \mathrm{H} a-2$ & $\mathrm{H} a-1, \mathrm{H}_{2}-2, \mathrm{Ha}-11, \mathrm{H}_{3}-15$ & $\mathrm{C}-3,5$ \\
\hline \multirow[t]{2}{*}{2} & $19.9 \mathrm{t}$ & $\mathrm{H} a 1.58 \mathrm{qt}(13.7,3.4)$ & $\mathrm{H}_{2}-1, \mathrm{He}-2, \mathrm{H}_{2}-3$ & $\mathrm{He}-1, \mathrm{H} a-1 \stackrel{\mathrm{g}}{,} \mathrm{H}_{3}-14, \mathrm{H}_{3}-15$ & \\
\hline & & He 1.45 dquint $(13.7,3.4)$ & $\mathrm{H} a-1, \mathrm{H} a-2, \mathrm{H}_{2}-3$ & & \\
\hline \multirow[t]{2}{*}{3} & $42.8 \mathrm{t}$ & $\mathrm{H} a 1.14$ td $(13.7,3.4)$ & $\mathrm{H}_{2}-2, \mathrm{He}-3$ & $\mathrm{He}-3, \mathrm{H}_{3}-13$ & $\mathrm{C}-14$ \\
\hline & & He $1.36 \mathrm{dt}(13.7,3.4)$ & $\mathrm{H}_{2}-2, \mathrm{H} a-3$ & $\mathrm{H}_{3}-13, \mathrm{H}_{3}-14$ & $\mathrm{C}-1,5$ \\
\hline 4 & $34.2 \mathrm{~s}$ & - & - & - & - \\
\hline 5 & $56.2 \mathrm{~d}$ & $1.17 \mathrm{dd}(12.9,2.5)$ & $\mathrm{H}_{2}-6$ & $\mathrm{He}-6, \mathrm{H} a-7, \mathrm{H}-9, \mathrm{H}_{3}-13$ & C- $4,6,9,10,14,15$ \\
\hline \multirow[t]{2}{*}{6} & $25.2 \mathrm{t}$ & Н $a 1.31 \mathrm{qd}(12.9,3.9)$ & $\mathrm{H}-5, \mathrm{He}-6, \mathrm{H}_{2}-7$ & $\mathrm{He}-6, \mathrm{He}-7, \mathrm{H}_{3}-14, \mathrm{H}_{3}-15$ & \\
\hline & & He 1.728 br d (12.9) & $\mathrm{H}-5, \mathrm{H} a-6, \mathrm{H} a-7$ & $\mathrm{H}-5, \mathrm{H} a-6, \mathrm{H}_{2}-7, \mathrm{H}_{3}-13$ & \\
\hline \multirow[t]{2}{*}{7} & $38.8 \mathrm{t}$ & $\mathrm{H} a 2.11 \mathrm{td}(12.9,4.8)$ & $\mathrm{H}_{2}-6, \mathrm{He}-7, \mathrm{Ha}-12$ & $\mathrm{H}-5, \mathrm{He}-6, \mathrm{He}-7$ & C- 8,12 \\
\hline & & He 2.36 ddd $(12.9,3.9,2.5)$ & $\mathrm{H}_{2}-6, \mathrm{H} a-7$ & $\mathrm{H}_{2}-6, \mathrm{H} a-7, \mathrm{Hb}-12$ & C-5,9,12 \\
\hline 8 & $150.1 \mathrm{~s}$ & - & - & - & - \\
\hline 9 & $50.2 \mathrm{~d}$ & $2.03-1.95$ AB type & $\mathrm{H}_{2}-11, \mathrm{H}_{2}-12$ & $\mathrm{H} a-1, \mathrm{H}-5, \mathrm{H}-5^{\prime}$ & C- $8,10,11,6^{\prime}$ \\
\hline 10 & $41.0 \mathrm{~s}$ & - & - & - & - \\
\hline \multirow[t]{2}{*}{11} & $22.2 \mathrm{t}$ & Ha $2.20 \mathrm{dd}(14.8,4.6)$ & H-9, Hb-11, Нa-12 & $\mathrm{He}-1, \mathrm{Hb}-11, \mathrm{H}_{3}-15, \mathrm{H}-5^{\prime}$ & $\mathrm{C}-8,9,10,1^{\prime}, 5^{\prime}, 6^{\prime}$ \\
\hline & & $\mathrm{Hb} 2.03-1.95 \mathrm{AB}$ type & H-9, Нa-11, Hb-12 & На-11, На-12, $\mathrm{H}_{3}-15$, H-5' & $\mathrm{C}-8,9,10$ \\
\hline \multirow[t]{2}{*}{12} & $108.0 \mathrm{t}$ & Ha 4.90 br s & Н $a-7, \mathrm{H}-9, \mathrm{Ha}-11, \mathrm{Hb}-12$ & $\mathrm{Hb}-11, \mathrm{Hb}-12, \mathrm{H}_{3}-15, \mathrm{H}-5^{\prime}$ & $\mathrm{C}-7,8,9$ \\
\hline & & $\mathrm{Hb} 4.79$ br s & H-9, Hb-11, Нa-12 & Нe-7, На-12 & C-7,9 \\
\hline 13 & $33.8 \mathrm{q}$ & $0.843 \mathrm{H}, \mathrm{s}$ & $\mathrm{H}_{3}-14$ & $\mathrm{H}_{2}-3, \mathrm{H}-5, \mathrm{He}-6$ & C- $3,4,5,14$ \\
\hline 14 & $22.0 \mathrm{q}$ & $0.783 \mathrm{H}, \mathrm{s}$ & $\mathrm{H}_{3}-13$ & $\mathrm{H} a-2, \mathrm{He}-3, \mathrm{H} a-6, \mathrm{H}_{3}-15$ & C- $3,4,5,13$ \\
\hline 15 & $15.1 \mathrm{q}$ & $0.703 \mathrm{H}, \mathrm{s}$ & & $\begin{array}{l}\mathrm{He}-1, \mathrm{H} a-2, \mathrm{H} a-6, \mathrm{H}_{2}-11, \\
\mathrm{Ha}-12, \mathrm{H}_{3}-14\end{array}$ & C-1,5,9,10 \\
\hline $1^{\prime}$ & $192.3 \mathrm{~s}$ & - & - & - & - \\
\hline $2^{\prime}$ & $120.4 \mathrm{~d}$ & $6.12 \mathrm{br} \mathrm{s}$ & $\mathrm{H}_{2}-7^{\prime}$ & $\mathrm{H}_{2}-7^{\prime}$ & $\mathrm{C}-3^{\prime}, 4^{\prime}, 6^{\prime}, 7^{\prime}$ \\
\hline $3^{\prime}$ & $164.5 \mathrm{~s}$ & - & - & - & - \\
\hline $4^{\prime}$ & $71.8 \mathrm{~s}$ & - & - & - & - \\
\hline $5^{\prime}$ & $74.7 \mathrm{~d}$ & $3.96 \mathrm{~s}$ & HO- $5^{\prime}$ & H-9, Hb-11, Нa-12, Н $a-8^{\prime}$ & $\mathrm{C}-11,1^{\prime}, 3^{\prime}, 4^{\prime}, 6^{\prime}, 8^{\prime}, 7^{\prime}$ \\
\hline $6^{\prime}$ & $85.2 \mathrm{~s}$ & - & - & - & - \\
\hline $7^{\prime}$ & $60.7 \mathrm{t}$ & $4.412 \mathrm{H}$, br s & $\mathrm{H}-2^{\prime}, \underline{\mathrm{HO}}-7^{\prime}$ & $\mathrm{H}-2^{\prime}, \mathrm{He}-8^{\prime}$ & $\mathrm{C}-2^{\prime}, 3^{\prime}$ \\
\hline \multirow[t]{2}{*}{$8^{\prime}$} & $43.3 \mathrm{t}$ & $\mathrm{H} a 2.91 \mathrm{~d}(17.2)$ & $\mathrm{He} e-8^{\prime}$ & $\mathrm{H}-5^{\prime}$ & C- $3^{\prime}, 4^{\prime}, 5^{\prime}, 9^{\prime}$ \\
\hline & & He $3.05 \mathrm{~d}(17.2)$ & $\mathrm{H} a-8^{\prime}$ & $\mathrm{H}_{2}-7^{\prime}$ & $\mathrm{C}-3^{\prime}, 4^{\prime}, 5^{\prime}, 9^{\prime}$ \\
\hline $9^{\prime}$ & $167.8 \mathrm{~s}$ & - & - & - & - \\
\hline $4^{\prime}-\mathrm{OH}$ & - & $4.90 \mathrm{br} \mathrm{s}$ & & & \\
\hline 5'-OH & - & $4.73 \mathrm{br} \mathrm{s}$ & $\mathrm{H}-5^{\prime}$ & & \\
\hline 7'-OH & - & $4.34 \mathrm{br} \mathrm{s}$ & $\mathrm{H}_{2}-7^{\prime}$ & & $\mathrm{C}-7^{\prime}$ \\
\hline
\end{tabular}

${ }^{a}$ The ${ }^{1} \mathrm{H}$ and ${ }^{13} \mathrm{C}$ NMR signals were assigned on the basis of DEPT, ${ }^{1} \mathrm{H}-{ }^{1} \mathrm{H}$ COSY, HMQC, HMBC, NOESY, and 1D difference NOE experiments; ${ }^{\mathrm{b}}$ Chemical shift values $\left(\delta_{\mathrm{H}}\right.$ and $\left.\delta_{\mathrm{C}}\right)$ were recorded using the solvent signals (acetone- $d_{6}$ : $\left.\delta_{\mathrm{H}} 2.05 / \delta_{\mathrm{C}} 29.83,206.26\right)$ as references, respectively; $\mathrm{H} a$ : axial proton; He: equatorial proton; ${ }^{\mathrm{c}}$ Multiplicities of the carbon signals were determined by DEPT experiments and are indicated as s (singlet), $\mathrm{d}$ (doublet), $\mathrm{t}$ (triplet) and $\mathrm{q}$ (quartet), respectively; ${ }^{\mathrm{d}}$ The numbers in each line of this column indicate the protons that correlated with the proton in the corresponding line in ${ }^{1} \mathrm{H}-{ }^{1} \mathrm{H}$ COSY; ${ }^{e}$ The numbers in each line of this column indicate the protons that showed NOE correlations with the proton in the corresponding line in NOESY or 1D difference NOE experiments. The NOEs between two protons in a spin coupling relationship were detected by the $1 \mathrm{D}$ difference NOE experiments; ${ }^{\mathrm{f}}$ The numbers in each line of this column indicate the carbons that showed HMBC correlations with the proton in the corresponding line in HMBC experiments optimized for the $8.3 \mathrm{~Hz}$ of long-range $J_{\mathrm{CH}}$ value; ${ }^{\mathrm{g}}$ Minus NOEs were detected on the protons $\mathrm{H} a-2$ and $\mathrm{H} a-1$ in the difference NOE experiments by irradiations at the protons $\mathrm{H} a-1$ and $\mathrm{H} a-2$, respectively. 
Interpretation of the ${ }^{1} \mathrm{H}-{ }^{1} \mathrm{H}$ COSY data coupled with $\mathrm{HMQC}$ established five spin systems, $\mathrm{C}-1 \rightarrow \mathrm{C}-3$, C-13-viaC-4-C-14, C-5 $\rightarrow$ C-7-viaC-8(C-8-C-12)-C-9-C-11, C-5'-OH, and C-2'-viaC-3'$\mathrm{C}-7^{\prime}-\mathrm{OH}$. The last one could be expanded to a conjugated enone moiety, $\mathrm{C}-\mathrm{1}^{\prime}-\mathrm{C}-2^{\prime}-\mathrm{C}-3^{\prime}-\mathrm{C}-7^{\prime}-\mathrm{OH}$, by the above mentioned information from UV and IR absorptions (Figure 2). The C-8' methylene was neighbored to the ester carbonyl C-9' according to the chemical shifts of both its protons and carbon $\left(\delta_{\mathrm{H}} 2.91\right.$ and $\left.3.05 ; \delta_{\mathrm{C}} 43.3\right)$. These structural moieties were further supported by the relevant HMBC correlations shown in Figure 2. At this stage, a tert-methyl group $\left(\mathrm{CH}_{3}-15\right)$, one $\mathrm{sp}^{3}(\mathrm{C}-10)$ and two oxygenated $\mathrm{sp}^{2}$ quaternary (C-4' and $\left.\mathrm{C}-6^{\prime}\right)$ carbons, and a hydroxyl group were remaining. The connectivity of these structural fragments was established on the basis of key HMBC correlations illustrated in Figure 2, which was also supported by the other related HMBC correlations (Table 1). Then, the ester carbonyl C-9' $\left(\delta_{\mathrm{C}} 167.8\right)$ could be linked to C- $6^{\prime}$ to form an ester linkage forming a six-membered ring according to the IR absorption at $1733 \mathrm{~cm}^{-1}$. Thus the remaining hydroxyl group was reasonably linked to C-4', leading to the planar structure of 1 (Figure 2).

Figure 2. Planar structure of 1 and selected UV, IR, ${ }^{1} \mathrm{H}-{ }^{1} \mathrm{H}$ COSY and HMBC data.

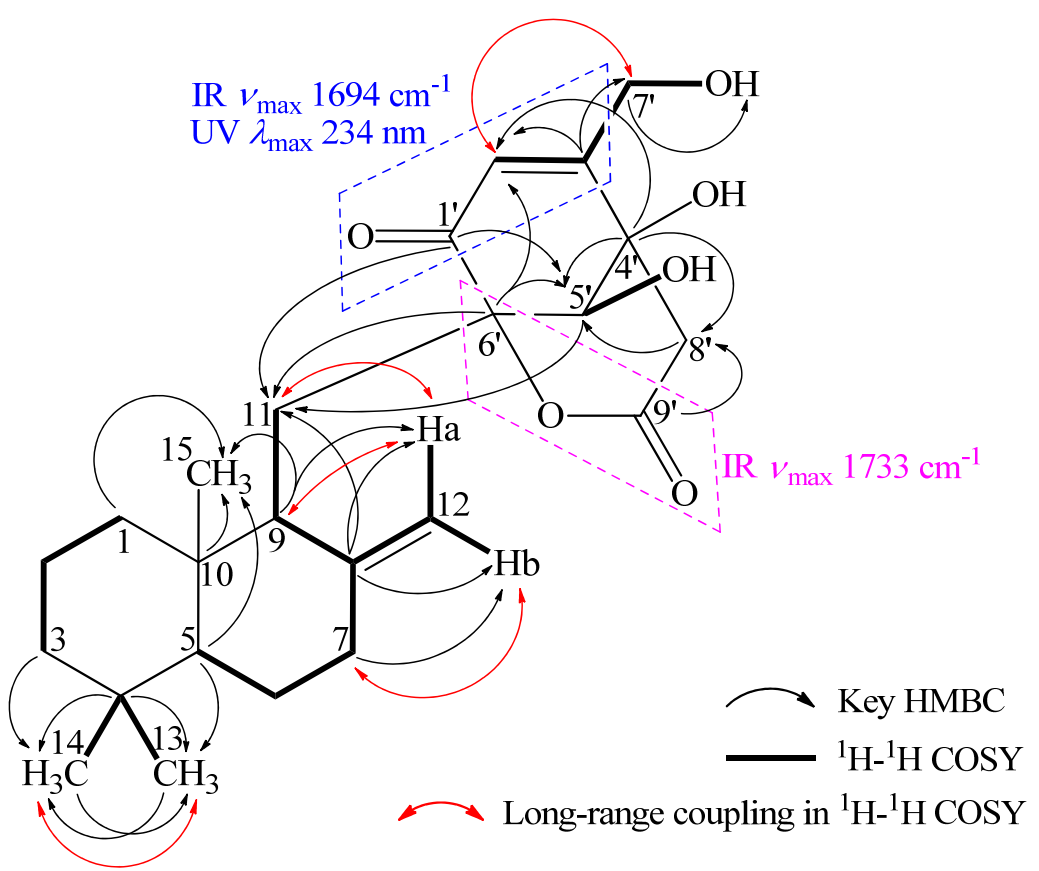

The relative stereochemistry (Figure 3) of 1 could be elucidated by NOEs and $J$ values of relevant protons (Table 1). NOEs on $\mathrm{H}_{3}-15 / \mathrm{H}_{3}-14$ and $\mathrm{H}_{3}-13 / \mathrm{H}-5$ indicated the trans-ring junction of two rings in drimene skeleton and chair-chair conformation of the two rings with an equatorial C-11 at C-9 was established by the key NOEs as shown in Figure 3. Other NOEs related and the splitting patterns and $J$ values of relevant protons (Table 1) accorded well with the conformation. NOEs on $\mathrm{H}-5^{\prime} / \mathrm{H} a-8^{\prime}$ and $\mathrm{H}_{2}-7^{\prime} / \mathrm{He}-8^{\prime}$ established the conformation of bridged cyclohexenone and lactone rings as shown in Figure 3, with which the up field chemical shift of C-9' $\left(\delta_{C} 167.8\right)$ could be explained by the shielding effect of conjugated enone group. 
Figure 3. Relative stereochemistry of $\mathbf{1}$ and selected NOE correlations.

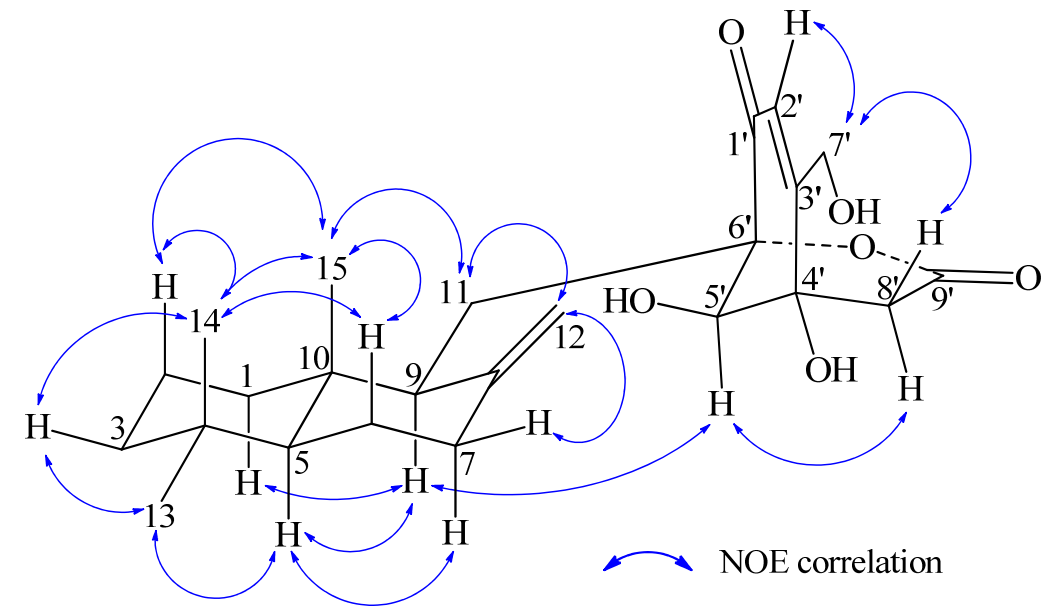

The drimene skeleton occurs both in $5 S 9 S 10 S[12-14,17,18]$ and $5 R 9 R 10 R[10,11,19-22]$ forms in Nature. The combination of drimenyl (C-11) and cyclohexenone moiety (C-6') affords four possible stereoisomers for $\mathbf{1}$, as two pairs of enantiomers with absolute configurations, $5 S 9 S 10 S 4^{\prime} R 5^{\prime} R 6^{\prime} S$ (A1) and $5 R 9 R 10 R 4^{\prime} S 5^{\prime} S 6^{\prime} R$ (A2), $5 S 9 S 10 S 4^{\prime} S 5^{\prime} S 6^{\prime} R$ (B1) and $5 R 9 R 10 R 4^{\prime} R 5^{\prime} R 6^{\prime} S$ (B2), respectively. Quantum chemical TDDFT [46] calculations were performed on all four stereoisomers to obtain their ECD spectra using the software package Gaussian 09 [47]. In the theoretical calculation, $\mathbf{A 2}$ and B1 gave ECD curves opposite to the experimental CD spectrum as shown for $\mathbf{A 2}$ in Figure 4 (see Supplementary Data S2 for B1). Thus, A2 and B1 were left out of consideration. Although the ECD spectrum of $\mathbf{A 1}$ best matched the experimental one (Figure 4), the absolute configuration of $\mathbf{1}$ was still insufficiently defined because B2 also reproduced properly the CD spectrum of $\mathbf{1}$ (Supplementary Data S2). A1 and B2 are diastereoisomers with an opposite drimenyl group and quite different specific optical rotations could be readily expected. We therefore calculated the specific optical rotations of $\mathbf{A 1}$ and $\mathbf{B 2}$ at the B3LYP/6-31G(d) level using B3LYP/6-31+G(d) geometries. This has afforded the calculated $[\alpha]_{\mathrm{D}}^{20}+15.1$ for $\mathbf{A} \mathbf{1}$ and $[\alpha]_{\mathrm{D}}^{20}+42.8$ for $\mathbf{B 2}$, respectively. The calculated $[\alpha]_{\mathrm{D}}^{20}$ value of $\mathbf{A 1}$ much better matched the measured $[\alpha]_{\mathrm{D}}^{20}+21.0(1.0, \mathrm{MeOH})$ of $\mathbf{1}$. Thus, the absolute configuration of 1 was assigned as $5 S 9 S 10 S 4^{\prime} R 5^{\prime} R 6^{\prime} S$.

Figure 4. Experimentally measured CD and calculated ECD spectra of $\mathbf{1}$ and $\mathbf{2}$.
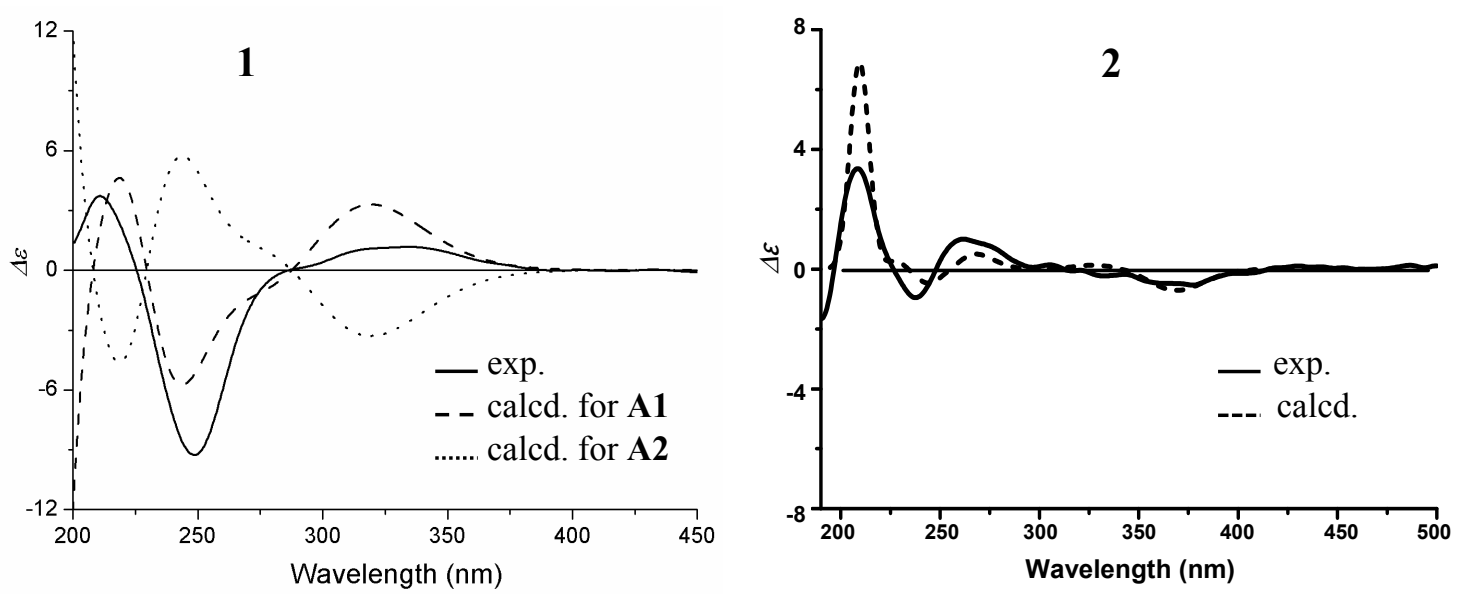
Further evidence also supported the absolute configuration of $\mathbf{1}$. First, the co-occurrence of $\mathbf{1}$ and $\mathbf{3}$ supported the same absolute stereochemistry of drimenyl in $\mathbf{1}$ and $\mathbf{3}$ from biogenetic considerations. Secondly, predicted $\mathrm{CD}$ signs of $\mathrm{C}=\mathrm{C}-\mathrm{C}=\mathrm{O}$ for $\mathbf{1}$ by qualitative $\mathrm{MO}$ theory [48] and empirical $\mathrm{CD}$ rules $[49,50]$ supported the absolute configuration of cyclohexenone moiety in $\mathbf{1}$. The CD spectrum of 1 in $\mathrm{MeOH}$ showed positive $\mathrm{n}-\pi^{*}(335.5 \mathrm{~nm}, \Delta \varepsilon+1.16)$ and negative $\pi-\pi^{*}(249 \mathrm{~nm}, \Delta \varepsilon-9.27)$ Cotton effects of the $\alpha, \beta$-unsaturated ketone moiety. This opposite sign pattern was consistent with the general observations in conjugated cyclohexenones [49,50]. The rigid bicyclic system in $\mathbf{1}$ fixed the cyclohexenone ring in a sofa conformation with planar $\mathrm{C}=\mathrm{C}-\mathrm{C}=\mathrm{O}$ (Figure 5 ). The helicity rule for the inherently dissymmetric $\mathrm{C}=\mathrm{C}-\mathrm{C}=\mathrm{O}$ chromophore $[49,50]$ therefore could not be applied to the $\mathrm{n}-\pi^{*}$ $(>300 \mathrm{~nm})$ and $\pi-\pi^{*}(230-260 \mathrm{~nm})$ transitions of 1 . Fortunately, a chiral second sphere of conjugated cyclohexenone with planar $\mathrm{C}=\mathrm{C}-\mathrm{C}=\mathrm{O}$ showed that absolute configuration $\mathrm{A}$ (Figure 5) giving rise to a positive CD for the $n-\pi^{*}$ transition [48]. The same absolute configuration $\mathbf{A}$ in $\mathbf{1}$ (Figure 5) was reflected well by its positive $n-\pi^{*}$ Cotton effect. The positive CD sign of $n-\pi^{*}$ transition was also supported by careful examination of $\mathrm{CD}$ contributions from each ligand around $\mathrm{C}=\mathrm{C}-\mathrm{C}=\mathrm{O}$ in $\mathbf{1}(\mathbf{C}-\mathbf{E}$ in Figure 5) according to the sectors (B in Figure 5) of qualitative MO theory [48]. The structural skeleton with a lactone bridge across the cyclohexenone ring in $\mathbf{1}$ resulted in the localization of bridged lactone ring in the middle sector region. Signs of the $\mathrm{CD}$ contributions are just the opposite in middle and back sectors. Thus, the simple octant rule for the planar $\mathrm{C}=\mathrm{C}-\mathrm{C}=\mathrm{O}$ compounds could not be applied to 1, but the sectors in Figure 5 fitted well the case. In addition, the CD spectrum of 1 gave a positive Cotton effect at $210 \mathrm{~nm}(+3.72)$. The sign of this Cotton effect, due to the positive "axial chirality" contribution [49,50] of $4^{\prime}-\mathrm{CH}_{2}$ and 6 '-O groups, reflected also the structural feature of cyclohexene moiety in $\mathbf{1}$ (Figure 5).

Figure 5. Stereo view of the cyclohexenone moiety and the prediction of CD signs for 1. (A) A chirality of the second sphere for the conjugated cyclohexenone with a planar $\mathrm{C}=\mathrm{C}-\mathrm{C}=\mathrm{O}$ chromophore. The depicted absolute configuration $\mathbf{A}$ gives rise to a positive $\mathrm{CD}$ for the $n-\pi^{*}(>300 \mathrm{~nm})$ transition [48]; (B) Sectors for the $\mathrm{n}-\pi^{*}(>300 \mathrm{~nm})$ transition of planar $\mathrm{C}=\mathrm{C}-\mathrm{C}=\mathrm{O}$ chromophore and the $\mathrm{CD}$ signs of ligand contributions in each sector [48]. Colored rectangular planes with a black ellipse indicate two nodal surfaces, by which the front, middle and back sector regions are divided; $(\mathbf{C}-\mathbf{E})$ Octant-like projection for $\mathbf{1}$ on the plane that parallels the nodal surfaces in $(\mathbf{B})$, which shows the ligands that located in the front $(\mathbf{C})$, middle (D) and back (E) sectors (showing only perturbing atoms), respectively. Signs of the ligand contributions are given for each sector.
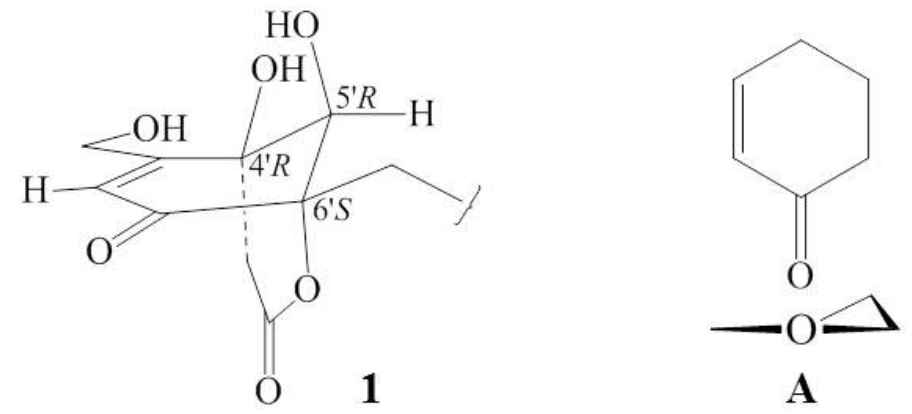
Figure 5. Cont.
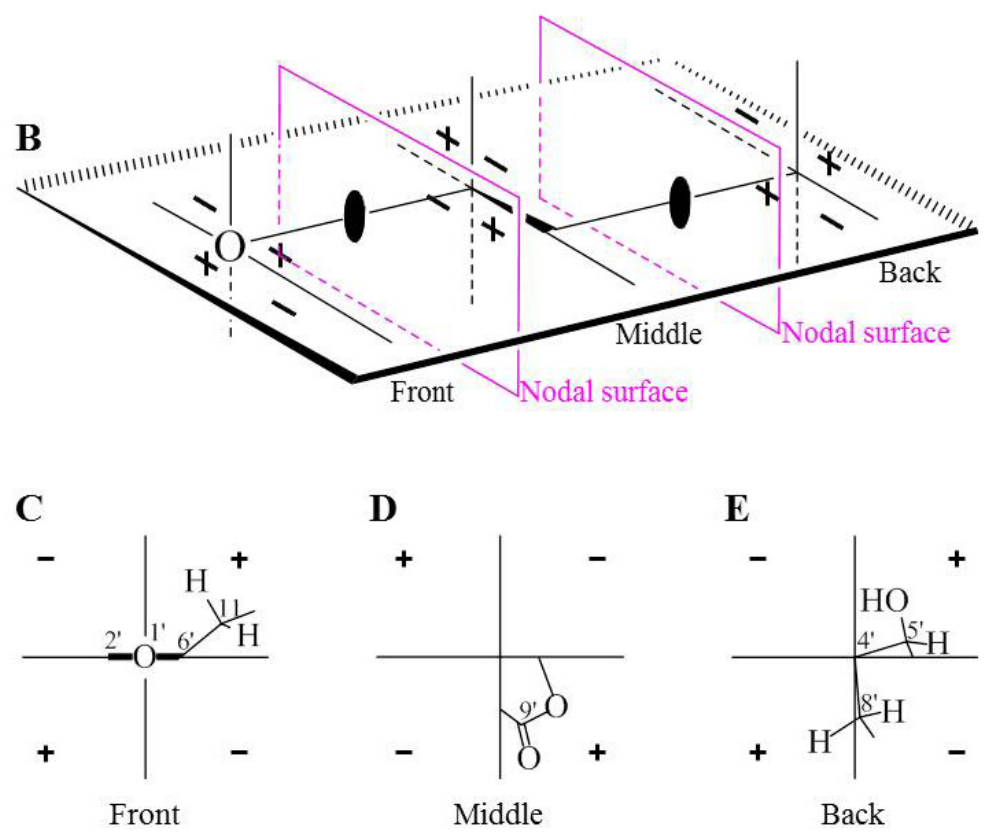

A literature survey showed that purpurogemutantin (1) is a new drimene meroterpenoid structurally novel in carrying a bridged bicyclic system composed of a conjugated cyclohexenone and a six-membered lactone rings. To our best knowledge, $\mathbf{1}$ is the first drimenyl cyclohexenone derivative with the mentioned bridged bicyclic system.

Purpurogemutantidin (2) was obtained as a colorless oil from $\mathrm{MeOH}$ and showed $[\alpha]_{\mathrm{D}}^{20}-13.7(c 0.1$, $\mathrm{CHCl}_{3}$ ). The elemental composition of $2, \mathrm{C}_{22} \mathrm{H}_{32} \mathrm{O}_{4}$ (7 double bond equivalents), was established by HRESIMS $\left(\mathrm{m} / \mathrm{z} 361.2377[\mathrm{M}+\mathrm{H}]^{+} ; \Delta=+0.2 \mathrm{mmu}\right)$. The UV and IR absorptions suggested the presence of hydroxyl (IR $v_{\max } 3392 \mathrm{~cm}^{-1}$ ) and ene(di)one (UV $\lambda_{\max } 236 \mathrm{~nm}, \log \varepsilon$ 4.00; IR $v_{\max }$ $1682 \mathrm{~cm}^{-1}$ ) [28] groups in 2. Its ${ }^{1} \mathrm{H}$ and ${ }^{13} \mathrm{C} \mathrm{NMR}$ data in $\mathrm{CDCl}_{3}$ (Table 2), analyzed with the aid of DEPT, ${ }^{1} \mathrm{H}-{ }^{1} \mathrm{H}$ COSY, HMQC and HMBC, indicated the characteristic signals of drimene residue seen both in macrophorins [27,28] and purpurogemutantin (1). The same chair-chair conformation of the drimenyl residue in $\mathbf{2}$ as that in $\mathbf{1}$ (Figure 3) was established by NOESY and difference NOE experiments: Key NOEs were detected between protons, $\mathrm{H} a-1 / \mathrm{H}-9, \mathrm{He}-1 / \mathrm{H} a-2, \mathrm{He}-1 / \mathrm{H}_{3}-15, \mathrm{H} a-2 / \mathrm{H}_{3}-14$, $\mathrm{H} a-2 / \mathrm{H}_{3}-15, \mathrm{He}-3 / \mathrm{H}_{3}-13, \mathrm{He}-3 / \mathrm{H}_{3}-14, \mathrm{H} a-3 / \mathrm{H}_{3}-13, \mathrm{H}-5 / \mathrm{He}-6, \mathrm{H}-5 / \mathrm{H} a-7, \mathrm{H}-5 / \mathrm{H}-9, \mathrm{H}-5 / \mathrm{H}_{3}-13$, $\mathrm{H} a-6 / \mathrm{He}-7, \mathrm{H} a-6 / \mathrm{H}_{3}-14, \mathrm{H} a-6 / \mathrm{H}_{3}-15$, $\mathrm{He}-7 / \mathrm{Ha}-12, \mathrm{H}_{2}-11 / \mathrm{Hb}-12, \mathrm{H}_{2}-11 / \mathrm{H}_{3}-15$, and $\mathrm{H}_{3}-14 / \mathrm{H}_{3}-15$, respectively. The other NOEs and the splitting patterns and $J$ values of relevant protons (Table 2) also supported the same conformation. Then, further detailed analysis of the ${ }^{1} \mathrm{H}-{ }^{1} \mathrm{H}$ COSY, HMQC and HMBC data (Table 2) demonstrated the presence of a cyclo-2-hexene-1,4-dione derived moiety attached to $\mathrm{C}-11$ in 2: HMBC correlations were observed from $\mathrm{H}_{2}-11$ to $\mathrm{C}-8, \mathrm{C}-9, \mathrm{C}-10, \mathrm{C}-1^{\prime}$ and C-6'; from $\mathrm{H}-2^{\prime}$ to $\mathrm{C}-3^{\prime}, \mathrm{C}-4^{\prime}, \mathrm{C}-6^{\prime}$ and $\mathrm{C}-7^{\prime}$; from $\mathrm{H}_{2}-7^{\prime}$ to $\mathrm{C}-2^{\prime}$ and $\mathrm{C}-3^{\prime}$; from Ha-5' to C-11, C-1', C-3', C-4' and C-6'; from $\mathrm{Hb}-5^{\prime}$ to $\mathrm{C}-11, \mathrm{C}-1^{\prime}, \mathrm{C}-4^{\prime}$ and $\mathrm{C}-6^{\prime}$; and from the $6^{\prime}-\mathrm{O} \underline{\mathrm{H}}$ proton to $\mathrm{C}-1^{\prime}, \mathrm{C}-5^{\prime}$ and C-6'. A remaining hydroxyl group was thus reasonably located at $\mathrm{C}-\mathbf{7}^{\prime}$ of $\mathbf{2}$. The ESIMS, HRESIMS, UV, IR, ${ }^{1} \mathrm{H}$ and ${ }^{13} \mathrm{C}$ NMR, DEPT, ${ }^{1} \mathrm{H}-{ }^{1} \mathrm{H}$ COSY, HMQC, HMBC, and NOESY spectra of 2 are provided as supporting information in Supplementary Data S3. 
Table 2. $400 \mathrm{MHz}{ }^{1} \mathrm{H}$ and $100 \mathrm{MHz}{ }^{13} \mathrm{C}$ NMR data of 2 in $\mathrm{CDCl}_{3}{ }^{\text {a }}$.

\begin{tabular}{|c|c|c|c|c|c|}
\hline Position & $\delta_{C}^{b, c}$ & $\delta_{\mathrm{H}}^{\mathrm{b}}(J$ in $\mathrm{Hz})$ & $\operatorname{COSY}^{d}$ & NOE $^{\mathrm{e}}$ & HMBC $^{\text {f }}$ \\
\hline \multirow[t]{2}{*}{1} & $38.7 \mathrm{t}$ & $\mathrm{H} a 1.07 \mathrm{td}(12.6,4.8)$ & $\mathrm{He}-1, \mathrm{H}_{2}-2$ & $\mathrm{He}-1, \mathrm{H}-9$ & $\mathrm{C}-3,5$ \\
\hline & & $\mathrm{He} 1.63$ br d (12.6) & $\mathrm{H} a-1, \mathrm{H} a-2$ & $\mathrm{H} a-1, \mathrm{H} a-2, \mathrm{H}_{3}-15$ & \\
\hline \multirow[t]{3}{*}{2} & $19.3 \mathrm{t}$ & $1.56-1.452 \mathrm{H}, \mathrm{AB}$ type $\mathrm{m}$ & & & C- $-4,10$ \\
\hline & & $\mathrm{H} a$ at lower field & $\mathrm{H}_{2}-1, \mathrm{H}_{2}-3$ & $\mathrm{H}_{3}-14, \mathrm{H}_{3}-15$ & \\
\hline & & $\mathrm{He}$ at higher field & $\mathrm{H}_{2}-1, \mathrm{H}_{2}-3$ & $\mathrm{H} a-1$ & \\
\hline \multirow[t]{2}{*}{3} & $42.0 \mathrm{t}$ & $\mathrm{H} a 1.18$ td $(12.4,4.8)$ & $\mathrm{H}_{2}-2, \mathrm{He}-3$ & $\mathrm{He}-3, \mathrm{H}_{3}-13$ & $\mathrm{C}-14$ \\
\hline & & $\mathrm{He} 1.37$ br d (12.4) & $\mathrm{H}_{2}-2, \mathrm{H} a-3$ & $\mathrm{H} a-3, \mathrm{H}_{3}-13, \mathrm{H}_{3}-14$ & $\mathrm{C}-1,5,14$ \\
\hline 4 & $33.7 \mathrm{~s}$ & - & - & - & - \\
\hline 5 & $55.6 \mathrm{~d}$ & $1.13 \mathrm{dd}(12.8,2.4)$ & $\mathrm{H}_{2}-6$ & $\mathrm{He}-6, \mathrm{H} a-7, \mathrm{H}-9, \mathrm{H}_{3}-13$ & C- $6,9,10,14,15$ \\
\hline \multirow[t]{2}{*}{6} & $24.6 \mathrm{t}$ & $\mathrm{H} a 1.25 \mathrm{qd}(12.8,3.8)$ & $\mathrm{H}-5, \mathrm{H} e-6, \mathrm{H}_{2}-7$ & $\mathrm{He} e-6, \mathrm{He}-7, \mathrm{H}_{3}-14, \mathrm{H}_{3}-15$ & $\mathrm{C}-5,7$ \\
\hline & & Нe $1.74 \mathrm{dm}(12.8)$ & $\mathrm{H}-5, \mathrm{H} a-6, \mathrm{H}_{2}-7$ & $\mathrm{H}-5, \mathrm{H} a-6, \mathrm{H}_{3}-13$ & \\
\hline \multirow[t]{2}{*}{7} & $38.1 \mathrm{t}$ & $\mathrm{H} a 1.89 \operatorname{td}(12.8,5.2)$ & $\mathrm{H}_{2}-6, \mathrm{He}-7$ & $\mathrm{H}-5, \mathrm{He}-6, \mathrm{He}-7$ & $\mathrm{C}-8,12$ \\
\hline & & $\mathrm{He} 2.28 \mathrm{ddd}(12.8,3.8,2.4)$ & $\mathrm{H}_{2}-6, \mathrm{H} a-7$ & Н $a-6$, Н $a-7$, На-12 & C-5, $6,8,9,12$ \\
\hline 8 & $148.9 \mathrm{~s}$ & - & - & - & - \\
\hline 9 & $50.5 \mathrm{~d}$ & $1.77 \mathrm{t}(4.7)$ & $\mathrm{H}_{2}-11$ & $\mathrm{H} a-1, \mathrm{H}-5$ & C- $8,10,6^{\prime}$ \\
\hline 10 & $39.9 \mathrm{~s}$ & - & - & - & - \\
\hline 11 & $34.8 \mathrm{t}$ & $1.882 \mathrm{H}, \mathrm{d}(4.7)$ & H-9 & $\mathrm{He}-1, \mathrm{Hb}-12, \mathrm{H}_{3}-15$ & C- $8,9,10,1^{\prime}, 6^{\prime}$ \\
\hline \multirow[t]{2}{*}{12} & $107.1 \mathrm{t}$ & Ha 4.75 br s & $\mathrm{H} a-7, \mathrm{Hb}-12$ & $\mathrm{He}-7, \mathrm{Hb}-12$ & $\mathrm{C}-7,9$ \\
\hline & & $\mathrm{Hb} 4.25$ br s & Ha-12 & $\mathrm{H}_{2}-11, \mathrm{Ha}-12, \mathrm{H}_{3}-15$ & C-7,9 \\
\hline 13 & $33.5 \mathrm{q}$ & $0.853 \mathrm{H}, \mathrm{s}$ & $\mathrm{H}_{3}-14$ & $\mathrm{H} a-3, \mathrm{H}-5, \mathrm{He}-6$ & C- $3,4,5,14$ \\
\hline 14 & $21.6 \mathrm{q}$ & $0.753 \mathrm{H}, \mathrm{s}$ & $\mathrm{H}_{3}-13$ & $\mathrm{H} a-2, \mathrm{H} e-3, \mathrm{H} a-6, \mathrm{H}_{3}-15$ & $C-3,4,5,13$ \\
\hline 15 & $15.0 \mathrm{q}$ & $0.573 \mathrm{H}, \mathrm{s}$ & & $\begin{array}{l}\mathrm{He}-1, \mathrm{H} a-2, \mathrm{H} a-6, \mathrm{H}_{2}-11, \\
\mathrm{Hb}-12, \mathrm{H}_{3}-14\end{array}$ & C- $1,5,9,10$ \\
\hline $1^{\prime}$ & $201.2 \mathrm{~s}$ & - & - & - & - \\
\hline $2^{\prime}$ & $134.4 \mathrm{~d}$ & $6.82 \mathrm{br} \mathrm{s}$ & $\mathrm{H}_{2}-7^{\prime}$ & - & $\mathrm{C}-3^{\prime}, 4^{\prime}, 6^{\prime}, 7^{\prime}$ \\
\hline $3^{\prime}$ & $150.9 \mathrm{~s}$ & - & - & - & - \\
\hline $4^{\prime}$ & $196.6 \mathrm{~s}$ & - & - & - & - \\
\hline \multirow[t]{2}{*}{$5^{\prime}$} & $53.1 \mathrm{t}$ & Ha 3.12 d (16.0) & $\mathrm{Hb}-5^{\prime}$ & $\mathrm{Hb}-5^{\prime}, \mathrm{H}_{2}-11$ & $\mathrm{C}-11,1^{\prime}, 3^{\prime}, 4^{\prime}, 6^{\prime}$ \\
\hline & & $\mathrm{Hb} 2.97 \mathrm{~d}(16.0)$ & Ha- $5^{\prime}$ & Ha- $5^{\prime}$ & $\mathrm{C}-11,1^{\prime}, 4^{\prime}, 6^{\prime}$ \\
\hline $6^{\prime}$ & $77.4 \mathrm{~s}$ & - & - & - & - \\
\hline \multirow[t]{2}{*}{$7^{\prime}$} & $59.6 \mathrm{t}$ & Ha 4.54 br d (17.2) & $\mathrm{H}-2^{\prime}, \mathrm{Hb}-7^{\prime}$ & $\mathrm{Hb}-7^{\prime}$ & $\mathrm{C}-2^{\prime}, 3^{\prime}$ \\
\hline & & $\mathrm{Hb} 4.44$ br d (17.2) & H-2', Ha-7' & На- $7^{\prime}$ & $\mathrm{C}-2^{\prime}, 3^{\prime}$ \\
\hline $6^{\prime}-\mathrm{OH}$ & - & $3.87 \mathrm{br} \mathrm{s}$ & - & & $C-1^{\prime}, 5^{\prime}, 6^{\prime}$ \\
\hline 7'-OH & - & $3.48 \mathrm{br} \mathrm{s}$ & - & & \\
\hline
\end{tabular}

a The ${ }^{1} \mathrm{H}$ and ${ }^{13} \mathrm{C}$ NMR signals were assigned on the basis of DEPT, ${ }^{1} \mathrm{H}^{-1} \mathrm{H}$ COSY, HMQC, HMBC, NOESY, and 1D difference NOE experiments; ${ }^{\mathrm{b}}$ Chemical shift values $\left(\delta_{\mathrm{H}}\right.$ and $\left.\delta_{\mathrm{C}}\right)$ were recorded using the solvent signals $\left(\mathrm{CDCl}_{3}\right.$ : $\left.\delta_{\mathrm{H}} 7.26 / \delta_{\mathrm{C}} 77.1\right)$ as references, respectively; $\mathrm{H} a$ : axial proton; He: equatorial proton; ${ }^{\mathrm{c}}$ Multiplicities of the carbon signals were determined by DEPT experiments and are shown as s (singlet), $d$ (doublet), $t$ (triplet) and q (quartet), respectively; ${ }^{d}$ The numbers in each line of this column indicate the protons that correlated with the proton in the corresponding line in ${ }^{1} \mathrm{H}-{ }^{1} \mathrm{H}$ COSY; ${ }^{e}$ The numbers in each line of this column indicate the protons that showed NOE correlations with the proton in the corresponding line in NOESY or 1D difference NOE experiments. The NOEs between two protons in a spin coupling relationship were detected by the $1 \mathrm{D}$ difference NOE experiments; ${ }^{\mathrm{f}}$ The numbers in each line of this column indicate the carbons that showed HMBC correlations with the proton in the corresponding line in the HMBC experiments optimized for the $8.3 \mathrm{~Hz}$ of long-range $J_{\mathrm{CH}}$ value. 
There are also four possible stereoisomers belonging to two pairs of enantiomers, with the absolute configurations $5 S 9 S 10 S 6^{\prime} S, 5 S 9 S 10 S 6^{\prime} R, 5 R 9 R 10 R 6^{\prime} S$ and $5 R 9 R 10 R 6^{\prime} R$, by connecting the drimenyl group (C-11) to the cyclohexenedione moiety (C-6') for 2 . In ECD calculations on all four possible stereoisomers with respect to the drimene skeleton and C-6', only one result matched the experimental CD spectrum of 2 (Figure 4) well, leading to the absolute configuration of 2 as $5 S 9 S 10 S 6$ 'S (Figure 1). Calculated ECD spectra of all four questionable stereoisomers and their comparisons with the experimental CD spectrum of $\mathbf{2}$ are given as supporting information in Supplementary Data S2.

Recently, Lin et al. reported a new drimene meroterpenoid with the same structure as $\mathbf{2}$ and named it penicilliumin A [31]. The authors assigned the relative stereochemistry of the drimenyl in penicilliumin A, being the same as that in $\mathbf{2}$, but did not determine its full absolute configuration. The ${ }^{13} \mathrm{C}$ NMR data of 2 are coincident with those of penicilliumin A [31], however, the two compounds had a quite different appearance and specific optical rotation: Compound 2, a colorless oil $(\mathrm{MeOH}),[\alpha]_{\mathrm{D}}^{20}-13.7$ $\left(c 0.1, \mathrm{CHCl}_{3}\right),[\alpha]_{\mathrm{D}}^{20}-9.3(c 0.5, \mathrm{MeOH})$; penicilliumin $\mathrm{A}$, white crystalline solid, $[\alpha]_{\mathrm{D}}^{20}-0.008(c 0.85$, $\mathrm{CHCl}_{3}$ ). In view of the presence of four possible stereoisomers together with the incompletely defined structure of penicilliumin A, we designated purpurogemutantidin (2) as a new compound.

Figure 6. Plausible biosynthetic pathways of 1-3.

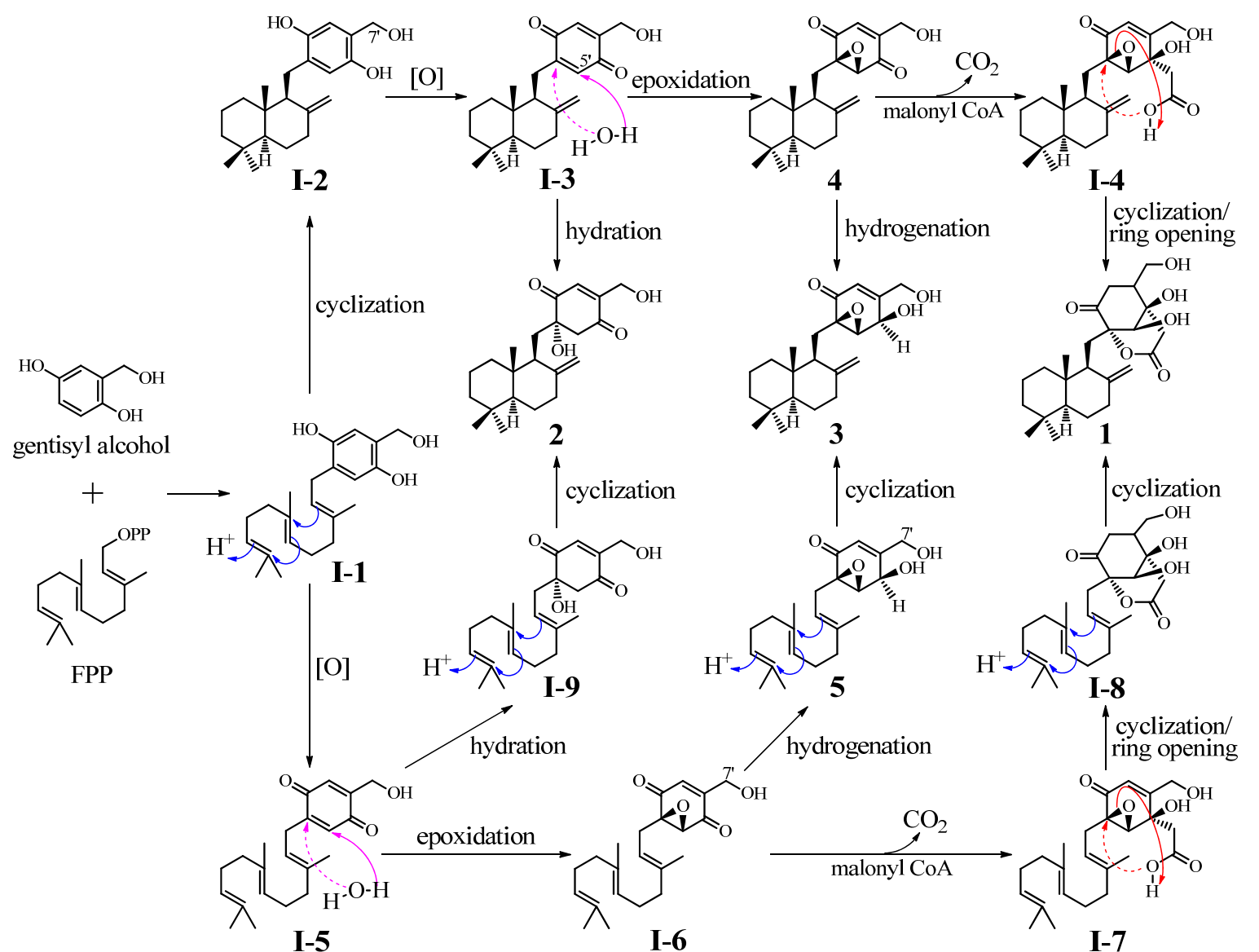

Plausible biosynthetic pathways for 1-3 are proposed in Figure 6. A co-intermediate of the 1-3 biosynthesis is proposed to be $\mathbf{I}-\mathbf{1}$, which might be produced by enzymatic reaction of gentisyl alcohol and farnesyl pyrophosphate (FPP), a biosynthetic precursor of all sesquiterpenoids [51]. Gentisyl alcohol has been isolated from fungal sources and is known to be biosynthesized via the polyketide 
pathway [52,53]. A straightforward cyclization of the farnesyl group in I-1, followed by oxidation of gentisyl phenols and then epoxidation on the formed para-quinone ring, would give intermediates I-2, I-3, and 4. The C-7' carbaldehyde form of I-2 [16], 5'-hydroxy I-3 (tauranin) [12,13,17] and macrophorin A (4) [24] have been isolated from fungal metabolites. The hydration of I-3 and hydrogenation of 4 would produce compounds 2 and 3 . On the other hand, malonylation of macrophorin A (4) followed by decarboxylation would give the intermediate I-4. Then, cyclization of I-4 accompanied with the epoxy ring opening would give compound 1. Another possibility is that the intermediate I-1 underwent chemical modifications on the gentisyl alcohol moiety at first to produce final intermediates I-9, 5 and I-8 via the intermediates I-5, I-6 and I-7 (Figure 6). Then, cyclization of the farnesyl groups in I-8, I-9 and 5 would also afford compounds 1, 2 and 3, respectively. This possibility was supported by isolation of $\mathbf{5}$ (22-deacetylyanuthone A), 7'-acetyl $\mathbf{5}$ (yanuthone A), and 7'-acetyl I-6 (yanuthone B) from a marine-derived fungus [54].

\subsection{Inhibitory Effects of 1-3 on Several Human Cancer Cell Lines}

Both new compounds 1 and $\mathbf{2}$ significantly inhibited the human chronic leukemia K562, acute leukemia HL-60, cervical cancer HeLa, gastric adenocarcinoma BGC-823 and breast cancer MCF-7 cells, with the inhibition rates (IR\%) ranging from $62.8 \%-88.0 \%$ at $100 \mu \mathrm{g} / \mathrm{mL}$ in the MTT assay (Table 3). Docetaxol and 5-fluorouracil as positive controls showed similar inhibition at the same concentration. The half inhibitory concentrations $\left(\mathrm{IC}_{50}, \mu \mathrm{M}\right)$ of $\mathbf{1}$ and $\mathbf{2}$ on the K562, HL-60, HeLa, BGC-823 and MCF-7 cells were determined by the MTT method and are given in Table 4.

Table 3. Inhibitory effects of $\mathbf{1}$ and $\mathbf{2}$ on human cancer cell lines tested by MTT assay.

\begin{tabular}{lccccc}
\hline \multirow{2}{*}{ Sample } & \multicolumn{5}{c}{ IR\% Value at the $\mathbf{1 0 0} \boldsymbol{\mu g} / \mathbf{m L}$ Test Sample } \\
\cline { 2 - 6 } & $\mathbf{K 5 6 2}$ & HL-60 & HeLa & BGC-823 & MCF-7 \\
\hline $\mathbf{1}$ & $62.8 \%$ & $74.5 \%$ & $88.0 \%$ & $87.3 \%$ & $86.5 \%$ \\
$\mathbf{2}$ & $71.3 \%$ & $70.9 \%$ & $83.1 \%$ & $81.3 \%$ & $77.7 \%$ \\
docetaxol & $71.2 \%$ & $74.9 \%$ & $84.4 \%$ & $70.2 \%$ & $69.7 \%$ \\
5-fluorouracil & $57.6 \%$ & $66.3 \%$ & $78.4 \%$ & $69.1 \%$ & $66.6 \%$ \\
\hline
\end{tabular}

The cells were treated with the sample at $100 \mu \mathrm{g} / \mathrm{mL}$ for $48 \mathrm{~h}$, and the inhibitory effect was assayed by the MTT method. Docetaxol and 5-fluorouracil were used as positive control.

Table 4. The $\mathrm{IC}_{50}(\mu \mathrm{M})$ of $\mathbf{1}$ and $\mathbf{2}$ on human cancer cell lines by MTT assay.

\begin{tabular}{lccccc}
\hline Compound & K562 & HL-60 & HeLa & BGC-823 & MCF-7 \\
\hline $\mathbf{1}$ & 13.4 & 18.1 & 18.9 & 33.0 & 29.3 \\
$\mathbf{2}$ & 0.93 & 2.48 & 16.6 & 31.0 & 26.3 \\
\hline
\end{tabular}

The cells were treated with the compound at series concentrations for $48 \mathrm{~h}$, and the half inhibitory concentration $\left(\mathrm{IC}_{50}\right)$ of the compound was determine by the MTT assay.

The inhibitory effect of the known compound macrophorin A (3) was also assayed using the K562 and HL-60 cells by the MTT method. Compound 3 significantly inhibited the growth of K562 and HL-60 cells with $\mathrm{IC}_{50}$ values of 1.48 and $0.85 \mu \mathrm{M}$, respectively. This is the first record of its effect on human cancer cells, confirming the original finding of its cytotoxicity on murine L-5178Y cells [24]. 
The ethyl acetate extract of parent strain G59 did not show any inhibitory effect on the K562 cells at 1000 or $100 \mu \mathrm{g} / \mathrm{mL}$ [37]. An IR\% value of $5.4 \%$ at the $100 \mu \mathrm{g} / \mathrm{mL}$ was also detected for the G59 extract from its cultures fermented at the same time and same conditions with the mutant BD-1-6 in present study. Thus, the above mentioned structural and biological results on 1-3 revealed that 1-3 should be newly produced by the mutant BD-1-6 compared to its parent strain G59. This was further supported by the followed HPLC and LC-ESIMS analysis of the EtOAc extracts both from the parent G59 and its mutant BD-1-6.

\subsection{Experimental Verification of the Absence of 1-3 in the G59 Products by HPLC and LC-ESIMS}

The ethyl acetate extracts from G59 and its mutant BD-1-6 cultured at the same time and in the same conditions were subjected to HPLC and LC-ESIMS analysis under the same LC conditions using 1-3 as control.

In the HPLC analysis, 1-3 were eluted as peaks with retention times $\left(t_{R}\right)$ of 56.07 min (1), $57.92 \mathrm{~min}(2)$ and $58.82 \mathrm{~min}(3)$, respectively, and detected all as minor metabolites in the mutant BD-1-6 but not in the parent G59 (Figure 7 and Supplementary Data S4). The detection of 1-3 in BD-1-6 and their absence in G59 were also verified by the UV curves of both BD-1-6 and G59 at the same retention times (see details in Supplementary Data S4).

Figure 7. HPLC analysis of the compounds 1-3 and the BD-1-6 and G59 extracts. EtOAc extracts of both the mutant BD-1-6 and its parent G59 cultures fermented at the same time and in the same conditions were used for the HPLC analysis, and the same sample amounts were injected into a column and analyzed by the HPLC in the same conditions.
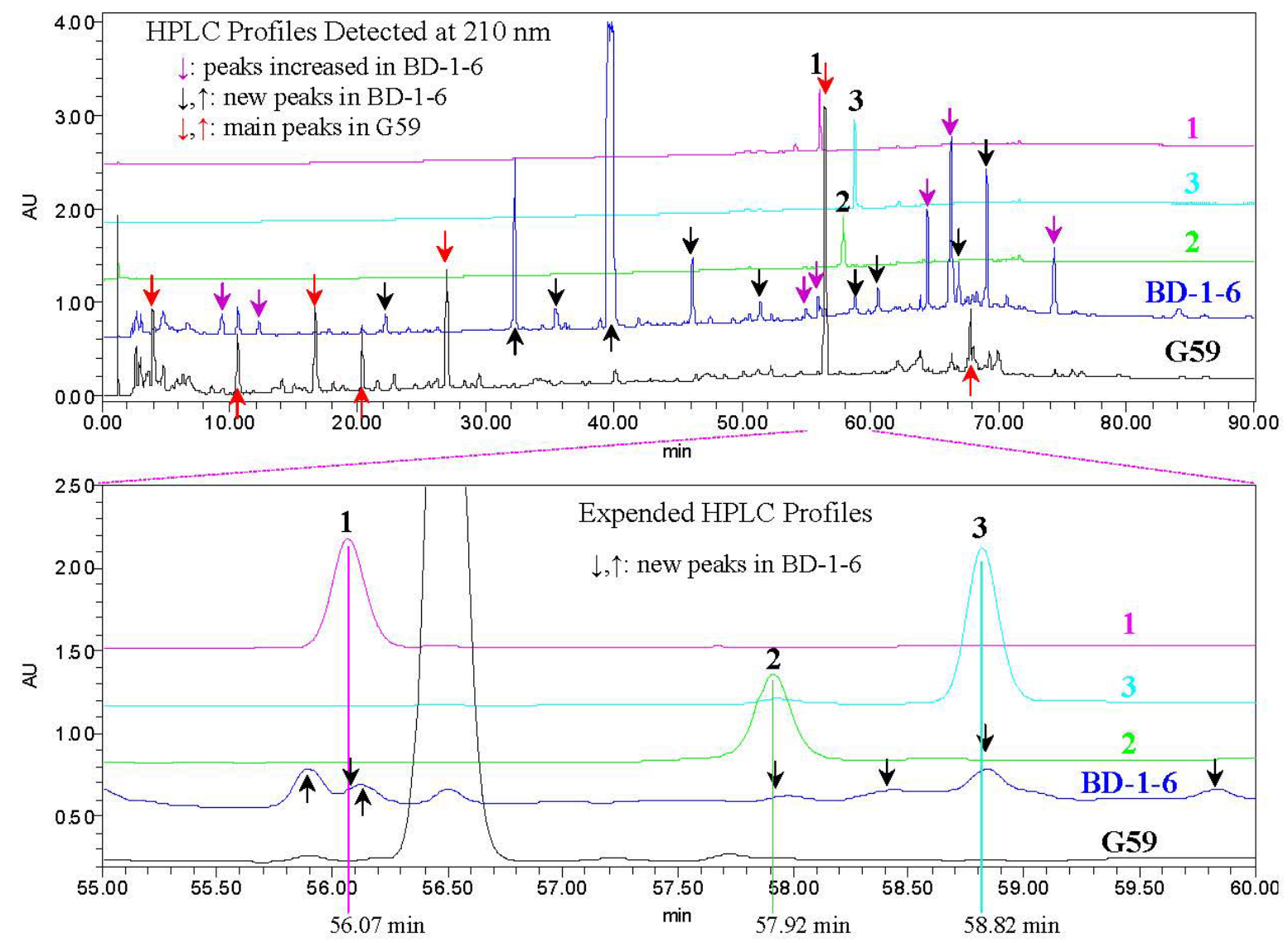
In the LC-ESIMS analysis, ion peaks of 1-3 appeared with shortened retention times $\left(t_{\mathrm{R}}: 52.3 \mathrm{~min}\right.$ for $\mathbf{1}, 53.8 \mathrm{~min}$ for $\mathbf{2}$, and $55.1 \mathrm{~min}$ for 3 ) than those in HPLC (Figure 7) because of the shortened flow length from the outlet of the HPLC column to the inlet of MS in LC-ESIMS. Examination of 1-3 in G59 and BD-1-6 were performed using selective ion $\left([\mathrm{M}+\mathrm{Na}]^{+}\right.$for $\mathbf{1}-\mathbf{3}$ and $[\mathrm{M}-\mathrm{H}]^{-}$for $\left.\mathbf{1}\right)$ monitoring with both chromatograms and related MS spectra. In the LC-ESIMS analysis, 1-3 were also detected only in BD-1-6 but entirely not in G59 (Supplementary Data S5), further confirming the above results of HPLC analysis.

All of the above mentioned results and discussions indicated that DES-induced mutation(s) in the mutant BD-1-6 activated some silent biosynthetic pathways in the parent strain G59, including one set of those for the 1-3 production (Figure 6), although detailed biological mechanisms remain unknown. Nevertheless, the discovery of $\mathbf{1}$ and $\mathbf{2}$ from BD-1-6 revealed that DES mutagenesis of the biosynthetically inactive fungal strains to produce bioactive metabolites is likely worth further investigation to search for new bioactive compounds by altering their secondary metabolisms.

\section{Experimental Section}

\subsection{General Experimental}

The melting point was measured on a Beijing Tiandiyu X-4 exact micro melting point apparatus (uncorrected). Optical rotations were measured on a Rudolph Research Autopol II spectropolarimeter. ESIMS was recorded on an Applied Biosystems API 3000 LC-MS spectrometer. HRESIMS was measured on an Agilent 6520 Q-TOF LC-MS spectrometer. UV data were recorded on a GBC Cintra 20 spectrophotometer, and IR spectra were taken on a Bruker Tensor-27 infrared spectrophotometer. CD data were recorded on a Biologic Science MOS 450 CD or a JASCO J-815 spectropolarimeter. $1 \mathrm{D}$ and 2D NMR spectra were obtained on a JEOL JNM-GX $400\left(400 \mathrm{MHz}{ }^{1} \mathrm{H}\right.$ and $\left.100 \mathrm{MHz}{ }^{13} \mathrm{C} \mathrm{NMR}\right)$ NMR spectrometer using the solvent signals $\left(\mathrm{CDCl}_{3}: \delta_{\mathrm{H}} 7.26 / \delta_{\mathrm{C}} 77.1\right.$; acetone- $d_{6}: \delta_{\mathrm{H}} 2.05 / \delta_{\mathrm{C}} 29.83$, 206.26; $\left.\mathrm{CD}_{3} \mathrm{OD}: \delta_{\mathrm{H}} 3.31 / \delta_{\mathrm{C}} 49.0\right)$ as references, respectively.

Precoated silica gel $\mathrm{GF}_{254}$ plates (Yantai Chemical Industrial Institute, Yantai, China) were used in TLC and spots were detected under UV light (254 and $365 \mathrm{~nm}$ ) or by using Vaughan's reagent [44] or 10\% sulfuric acid reagent. Silica gel (100-200 mesh, Yantai Chemical Industrial Institute, Yantai, China), YMC*GEL ${ }^{\circledR}$ ODS-A-HG (12 nm S-50 $\mu$ M, YMC Co. Ltd., Kyoto, Japan), and Sephadex ${ }^{\mathrm{TM}}$ LH-20 (GE Healthcare, Uppsala, Sweden) were used for column chromatography. Semi-preparative HPLC was performed using a Senshu Pak ODS 3251-D column $(8 \times 250 \mathrm{~mm}$; Senshu Scientific Co. Ltd., Tokyo, Japan) on a Waters HPLC equipment using Waters 600 controller, Waters 600 pump, Waters 2414 refractive index detector, Waters 2996 photodiode array detector and Waters Empower ${ }^{\mathrm{TM}}$ software.

Electronic circular dichroism (ECD) spectra for each of four stereoisomers of $\mathbf{1}$ and $\mathbf{2}$ were obtained by quantum chemical time-dependent density functional theory (TDDFT) [46] calculations using the software package Gaussian 09 [47]. Conformational searches were performed by using the MMFF94S molecular mechanics force field and charged with MMFF94. The resulting conformation were optimized by DFT at the B3LYP/6-31G level. The theoretical ECD calculations on the optimized conformers were performed by using the TDDFT method at B3LYP/6-311++G(2d,p) level. The polarizable continuum model (PCM) was adopted to consider solvent effects using the dielectric 
constant of methanol $(\varepsilon=32.6)$. The specific optical rotations of two diasteroisomers $\mathbf{A 1}$ and $\mathbf{B} 2$ for $\mathbf{1}$ were calculated at the B3LYP/6-31G(d) level using B3LYP/6-31+G(d) geometries.

\subsection{Fungal Strain and Human Cancer Cell Line}

P. purpurogenum G59 is a marine-derived wild-type fungal strain G59, which was isolated from a soil sample collected at the tideland of Bohai Bay around Lüjühe in Tianjin, China, in September 2004 [37] and identified by L. Guo, Institute of Microbiology, Chinese Academy of Sciences, Beijing, China. This strain was deposited at the China General Microbiological Culture Collection Center under the accession number CGMCC No. 3560. The strain G59 did not produce secondary metabolites showing antitumor effect on $\mathrm{K} 562$ cells, indicated by the inhibition rate (IR\%, lower than $6.9 \%$ at $1000 \mu \mathrm{g} / \mathrm{mL}$ in every test) of its EtOAc extract $[37,44]$ as also reconfirmed in the present study.

The producing strain $P$. purpurogenum BD-1-6 is a bioactive mutant obtained by random diethyl sulfate (DES) mutagenesis of the strain G59. The G59 spores in 20\% (v/v) DMSO containing 0.5\% $(\mathrm{v} / \mathrm{v})$ DES were stored at $4{ }^{\circ} \mathrm{C}$ for 1 day to treat the spores with DES. Then, single colony isolation was carried out using the treated G59 spores to obtain the mutant BD-1-6. The mutant strain BD-1-6 was deposited in the China General Microbiological Culture Collection Center under the accession number CGMCC No. 5525.

In the MTT assay for screening of bioactive mutants, the EtOAc extract of BD-1-6 culture significantly inhibited $\mathrm{K} 562$ cells (IR\%, 60.1\% at $100 \mu \mathrm{g} / \mathrm{mL}$ ), whereas the EtOAc extract of G59 culture fermented at the same time and in the same conditions in present study did not show any inhibitory effect on $\mathrm{K} 562$ cells (IR\%, $4.8 \%$ at $100 \mu \mathrm{g} / \mathrm{mL}$ ).

Human chronic myelogenous leukemia K562 cell line was provided by Song Li (Beijing Institute of Pharmacology and Toxicology). Human acute promyelocytic leukemia HL-60, human cervical cancer HeLa, Human gastric adenocarcinoma BGC-823 and human breast cancer MCF-7 cell lines were provide by Wenxia Zhou (Beijing Institute of Pharmacology and Toxicology). The cells were routinely maintained at $37{ }^{\circ} \mathrm{C}$ in RPMI-1640 medium supplemented with $10 \%(\mathrm{v} / \mathrm{v})$ fetal bovine serum in the presence of $100 \mu \mathrm{g} / \mathrm{mL}$ penicillin and streptomycin under a humidified atmosphere of $5 \% \mathrm{CO}_{2}$ and $95 \%$ air.

\subsection{Fermentation and EtOAc Extract Preparation}

Fresh spores of the mutant BD-1-6 were inoculated into a $500 \mathrm{~mL}$ Erlenmeyer flask containing $200 \mathrm{~mL}$ of liquid medium (glucose $2 \%$, maltose $1 \%$, mannitol $2 \%$, glutamic acid $1 \%$, peptone $0.5 \%$ and yeast extract $0.3 \%$ in distilled water, adjusted to $\mathrm{pH} 6.0$ prior to sterilization) and cultured at $28{ }^{\circ} \mathrm{C}$ for $48 \mathrm{~h}$ on a rotary shaker at $200 \mathrm{rpm}$. Each $10 \mathrm{~mL}$ of this culture broth was inoculated into 7 of $500 \mathrm{~mL}$ Erlenmeyer flasks containing $200 \mathrm{~mL}$ of the same liquid medium and further cultured under the same condition for $48 \mathrm{~h}$ to obtain a seed culture $(1400 \mathrm{~mL})$. Each $10 \mathrm{~mL}$ of the seed culture was inoculated into 100 of $500 \mathrm{~mL}$ Erlenmeyer flasks with $200 \mathrm{~mL}$ of the same liquid medium. Then, the producing fermentation was performed on rotary shaker at $200 \mathrm{rpm}$ at $28{ }^{\circ} \mathrm{C}$ for 12 days. The whole broth $(20 \mathrm{~L})$ was separated into a filtrate and a mycelial cake. The mycelial cake was extracted three times with $80 \%(\mathrm{v} / \mathrm{v})$ aqueous acetone $(10 \mathrm{~L})$ by ultrasonication for $2 \mathrm{~h}$. The aqueous acetone solution obtained by filtration was evaporated under reduced pressure to remove acetone. The remaining water 
layer $(6 \mathrm{~L})$ was extracted three times with equal volumes of EtOAc to give an extract $(17 \mathrm{~g})$. The EtOAc extracts showed an inhibitory effect on K562 cells with an IR\% value of $58.6 \%$ at $100 \mu \mathrm{g} / \mathrm{mL}$.

The original strain G59 was also fermented in the same manner as that for mutant BD-1-6 at the same time and same conditions using 3 of $500 \mathrm{~mL}$ Erlenmeyer flasks with $200 \mathrm{~mL}$ of the same liquid medium. Extraction of the whole broth $(600 \mathrm{~mL})$ as describe above for mutant BD-1-6 provided an EtOAC extract $(610 \mathrm{mg})$, which did not show any inhibitory effect on K562 cells (an IR\% value of $5.4 \%$ at $100 \mu \mathrm{g} / \mathrm{mL}$ ). This extract was used for assay and HPLC and LC-ESIMS analysis.

\subsection{Isolation of Compounds 1-3}

The EtOAc extract (17 g) of mutant BD-1-6 was subjected to silica gel column (silica gel $300 \mathrm{~g}$, bed $4.5 \times 40 \mathrm{~cm}$ ) chromatography by stepwise elution with dichloromethane (D)-acetone (A) $(100: 0 \rightarrow 0: 100)$ to obtain 6 fractions: Fr-1 (4.6 g, eluted by dichloromethane), Fr-2 (2.6 g, eluted by dichloromethane), Fr-3 (1.1 g, eluted by D-A 95:5), Fr-4 (3.1 g, eluted by D-A 95:5), Fr-5 (1.7 g, eluted by D-A 95:5 $\rightarrow 80: 20$ ), and Fr-6 ( 2 g, eluted by acetone). Fr-3 and Fr-5 showed inhibitory effect on K562 cells with the IR\% values of 56.9 and $45.2 \%$ at the $100 \mu \mathrm{g} / \mathrm{mL}$, respectively.

Fr-3 (1.1 g) was subjected again to a silica gel column (silica gel $25 \mathrm{~g}$, bed $1.5 \times 35 \mathrm{~cm}$ ) and a stepwise elution with cyclohexane (C)-acetone (A) (100:0 $\rightarrow 60: 40)$ giving 3 fractions: Fr-3-1 (480 mg, eluted by cyclohexane), Fr-3-2 (121 mg, eluted by C-A 95:5 $\rightarrow 85: 15)$, and Fr-3-3 (310 mg, eluted by C-A $80: 20 \rightarrow 75: 25 \rightarrow 60: 40)$. Fr-3-2 inhibited the K562 cells with an IR\% value of $62.1 \%$ at the $100 \mu \mathrm{g} / \mathrm{mL}$. The whole Fr-3-2 (121 mg) was separated by semi-preparative HPLC (Senshu Pak ODS 3251-D column, room temperature, mobile phase $\mathrm{MeOH}-\mathrm{H}_{2} \mathrm{O} 80: 20$, flow rate $2.0 \mathrm{~mL} / \mathrm{min}$, detecting wave lengths 210 and $254 \mathrm{~nm})$ to obtain $2\left(6.2 \mathrm{mg}\right.$, retention time $\left.t_{\mathrm{R}}=20.1 \mathrm{~min}\right)$.

Fr-5 (1.7 g) was subjected to a Sephadex LH-20 column (bed $2 \times 130 \mathrm{~cm}$ ) in $\mathrm{CH}_{2} \mathrm{Cl}_{2}-\mathrm{MeOH}(1: 1)$ and eluted with the same $\mathrm{CH}_{2} \mathrm{Cl}_{2}-\mathrm{MeOH}(1: 1)$ to afford 4 fractions in the order of elution: $\mathbf{F r - 5 - 1}$ (590 mg), Fr-5-2 (760 mg), Fr-5-3 (113 mg), and Fr-5-4 (230 mg). Fr-5-2 and Fr-5-3 inhibited the K562 cells with the IR\% values of 42.4 and $50.9 \%$ at the $100 \mu \mathrm{g} / \mathrm{mL}$, respectively. Fr-5-3 (113 mg) was separated by semi-preparative HPLC (Senshu Pak ODS 3251-D column, room temperature, mobile phase $\mathrm{MeOH}-\mathrm{H}_{2} \mathrm{O} 77: 23$, flow rate $2.0 \mathrm{~mL} / \mathrm{min}$, detecting wave lengths 210 and $254 \mathrm{~nm}$ ) to obtain $1\left(21 \mathrm{mg}, t_{\mathrm{R}}=21 \mathrm{~min}\right)$.

Fr-5-2 (760 mg) was further separated by Sephadex LH-20 column chromatography (bed $2 \times 130 \mathrm{~cm}$, eluting with $\left.\mathrm{CH}_{2} \mathrm{Cl}_{2}-\mathrm{MeOH} 1: 1\right)$ to give 3 fractions in the order of elution: Fr-5-2-1 (51 mg), Fr-5-2-2 (430 mg), and Fr-5-2-3 (270 mg). Fr-5-2-2 inhibited the K562 cells with an IR\% value of 58.8\% at the $100 \mu \mathrm{g} / \mathrm{mL}$. Fr-5-2-2 (430 mg) was thus subjected to a ODS column (bed $1.2 \times 10 \mathrm{~cm}$ ) and elution with $\mathrm{MeOH}-\mathrm{H}_{2} \mathrm{O}(20: 80 \rightarrow 95: 5)$ afforded 7 fractions: Fr-5-2-2-1 (11 mg, eluted by $\mathrm{MeOH}-\mathrm{H}_{2} \mathrm{O}$ 20:80 $\rightarrow 25: 75)$, Fr-5-2-2-2 (17 mg, eluted by $\mathrm{MeOH}-\mathrm{H}_{2} \mathrm{O}$ 30:70), Fr-5-2-2-3 (34 mg, eluted $\mathrm{MeOH}-\mathrm{H}_{2} \mathrm{O}$ 40:60 $\left.\rightarrow 60: 40\right)$, Fr-5-2-2-4 (107 mg, eluted by $\mathrm{MeOH}-\mathrm{H}_{2} \mathrm{O}$ 80:20), Fr-5-2-2-5 (25 mg, eluted by $\mathrm{MeOH}-\mathrm{H}_{2} \mathrm{O}$ 80:20), Fr-5-2-2-6 (14 mg, eluted by $\mathrm{MeOH}-\mathrm{H}_{2} \mathrm{O}$ 80:20), and Fr-5-2-2-7 ( $215 \mathrm{mg}$, eluted by $\mathrm{MeOH}-\mathrm{H}_{2} \mathrm{O}$ 95:5). Fr-5-2-2-4 inhibited the $\mathrm{K} 562$ cells with an IR\% value of $59.3 \%$ at the $100 \mu \mathrm{g} / \mathrm{mL}$. Thus, Fr-5-2-2-4 (107 mg) was further subjected to semi-preparative HPLC 
separation (Senshu Pak ODS 3251-D column, room temperature, mobile phase $\mathrm{MeOH}-\mathrm{H}_{2} \mathrm{O}$ 75:25, flow rate $2.0 \mathrm{~mL} / \mathrm{min}$, detecting wave lengths 210 and $254 \mathrm{~nm})$ to obtain $3\left(19 \mathrm{mg}, t_{\mathrm{R}}=39.6 \mathrm{~min}\right)$.

\subsection{MTT Assay}

The EtOAc extracts both from BD-1-6 and G59, compounds 1-3, 5-fluorouracil (5-FU) (Aladdin Chemistry Co. Ltd., lot No. 5402), and docetaxol (DOC) (Beijing Chimivo Technology Co. Ltd., lot No. 20110326) were dissolved in DMSO to prepare $10.0 \mathrm{mg} / \mathrm{mL}$ stock solutions, and serial dilutions of test samples were made for MTT assay. 5-FU and DOC were used as positive control, and DMSO was used as blank control.

Exponentially growing K562, HL-60, HeLa, BGC-823 and MCF-7 cells were suspended in fresh RPMI-1640 medium at the density of $2 \times 10^{4}$ cells $/ \mathrm{mL}$ and then seeded into 96-well plates at $200 \mu \mathrm{L} /$ well. The suspended K562 and HL-60 cells were incubated at $37{ }^{\circ} \mathrm{C}$ for $2 \mathrm{~h}$, whereas the adherent cells HeLa, BGC-823 and MCF-7 were incubated at $37{ }^{\circ} \mathrm{C}$ for $12 \mathrm{~h}$. Then, $2 \mu \mathrm{L}$ of DMSO for control and the test sample solutions was added to each well, and the cells were cultured at $37{ }^{\circ} \mathrm{C}$ for $48 \mathrm{~h}$. After morphological examination of the cells under a reversed phase microscope, MTT $(20 \mu \mathrm{L}$; $5 \mathrm{mg} / \mathrm{mL}$ in PBS) was added into each well, incubated at $37{ }^{\circ} \mathrm{C}$ for $4 \mathrm{~h}$, and centrifuged at $2000 \mathrm{rpm}$ for $20 \mathrm{~min}$. After removal of the supernatant by aspirating, $150 \mu \mathrm{L}$ DMSO was added into each well, and shaken for 5 min to dissolve formazan crystals. The OD value at $570 \mathrm{~nm}$ was read for each well using the VERSAmax-BN03152 plate reader. Each three wells were set for control and test groups, respectively, and the inhibition rate (IR\%) was calculated using OD mean values according to the formula, $\mathrm{IR} \%=\left(\mathrm{OD}_{\text {control }}-\mathrm{OD}_{\text {sample }}\right) / \mathrm{OD}_{\text {control }} \times 100 \%$. The $\mathrm{IC}_{50}$ value for a sample was obtained from the IR\% values of the sample at different concentrations.

\subsection{Physicochemical and Spectral Data for Compounds 1-3}

Purpurogemutantin (1): White crystalline powder $(\mathrm{MeOH}), \mathrm{mp} 122-123{ }^{\circ} \mathrm{C},[\alpha]_{\mathrm{D}}^{20}+21.0(c 1.0$, $\mathrm{MeOH})$. UV $\lambda_{\max } \mathrm{nm}(\log \varepsilon)$ in MeOH: 234 (3.87). IR $v_{\max } \mathrm{cm}^{-1}: 3405,2934,1733,1694,1459,1442$, $1388,1365,1277,1246,1229,1114,1067,1044,1021,889 . \mathrm{CD}(0.48 \mathrm{mM}, \mathrm{MeOH}) \Delta \varepsilon(\mathrm{nm})$ : 0 (388.5), +1.16 (335.5), 0 (286.5), -9.27 (249), 0 (225.5), +3.72 (210). ${ }^{1} \mathrm{H}$ and ${ }^{13} \mathrm{C}$ NMR data in acetone- $d_{6}$ : see Table 1. Positive ESIMS $m / z: 419[\mathrm{M}+\mathrm{H}]^{+}, 441[\mathrm{M}+\mathrm{Na}]^{+}, 837[2 \mathrm{M}+\mathrm{H}]^{+}$, $859[2 \mathrm{M}+\mathrm{Na}]^{+}$; negative ESI-MS $m / z: 531\left[\mathrm{M}+\mathrm{CF}_{3} \mathrm{CO}_{2}\right]^{-}$. Positive HRESIMS $\mathrm{m} / z$ : measured 419.2431 [M $+\mathrm{H}]^{+}$, calculated for $\mathrm{C}_{24} \mathrm{H}_{35} \mathrm{O}_{6}[\mathrm{M}+\mathrm{H}]$ 419.2434; measured $436.2692\left[\mathrm{M}+\mathrm{NH}_{4}\right]^{+}$, calculated for $\mathrm{C}_{24} \mathrm{H}_{38} \mathrm{NO}_{6}\left[\mathrm{M}+\mathrm{NH}_{4}\right]$ 436.2699; measured $441.2234[\mathrm{M}+\mathrm{Na}]^{+}$, calculated for $\mathrm{C}_{24} \mathrm{H}_{34} \mathrm{O}_{6} \mathrm{Na}[\mathrm{M}+\mathrm{Na}] 441.2253$.

Purpurogemutantidin (2): Colorless oil (MeOH), $[\alpha]_{\mathrm{D}}^{20}-13.7\left(c 0.1, \mathrm{CHCl}_{3}\right),[\alpha]_{\mathrm{D}}^{20}-9.3(c 0.5, \mathrm{MeOH})$; (penicilliumin A, white crystalline solid, $[\alpha]_{\mathrm{D}}^{20}-0.008\left(c 0.85, \mathrm{CHCl}_{3}\right)$ in literature [31]). UV $\lambda_{\max } \mathrm{nm}$ ( $\log \varepsilon$ ) in MeOH: 236 (4.00). IR $v_{\max } \mathrm{cm}^{-1}:$ 3392, 2941, 1682, 1457, 1443, 1388, 1368, 1243, 1208, 1092, 1036, 898, 829. CD (0.27 mM, MeOH) $\Delta \varepsilon(\mathrm{nm}): 0$ (415.5), -0.57 (360.5), 0 (320), +1.14 (260.5), 0 (247.6), -1.25 (237), 0 (226), +3.74 (209.5); CD $\lambda_{\max } \mathrm{nm}$ (mdeg) in $\mathrm{MeOH}$ at $100 \mu \mathrm{g} / \mathrm{mL}: 415.5$ (0), 360.5 (-0.52177), 320 (0), 260.5 (+1.04783), 247.6 (0), 237 (-1.14715), 226 (0), 209.5 (+3.42439). ${ }^{1} \mathrm{H}$ and ${ }^{13} \mathrm{C}$ NMR data in $\mathrm{CDCl}_{3}$ : see Table 2. Positive ESIMS $m / z: 383[\mathrm{M}+\mathrm{Na}]^{+}$; negative ESIMS 
$m / z: 341\left[\mathrm{M}-\mathrm{H}_{2} \mathrm{O}-\mathrm{H}\right]^{-}, 359[\mathrm{M}-\mathrm{H}]^{-}, 395[\mathrm{M}+\mathrm{Cl}]^{-}$. Positive HRESIMS $m / z$ : measured 743.4486 $[2 \mathrm{M}+\mathrm{Na}]^{+}$, calculated for $\mathrm{C}_{44} \mathrm{H}_{64} \mathrm{O}_{8} \mathrm{Na}[2 \mathrm{M}+\mathrm{Na}]$ 743.4499; measured $399.1939[\mathrm{M}+\mathrm{K}]^{+}$, calculated for $\mathrm{C}_{22} \mathrm{H}_{32} \mathrm{O}_{4} \mathrm{~K}[\mathrm{M}+\mathrm{K}]$ 399.1938; measured $383.2193[\mathrm{M}+\mathrm{Na}]^{+}$, calculated for $\mathrm{C}_{22} \mathrm{H}_{32} \mathrm{O}_{4} \mathrm{Na}[\mathrm{M}+\mathrm{Na}]$ 383.2198; measured 361.2377 [M+H] , calculated for $\mathrm{C}_{22} \mathrm{H}_{33} \mathrm{O}_{4}[\mathrm{M}+\mathrm{H}]$ 361.2379; measured 343.2269 $\left[\mathrm{M}-\mathrm{H}_{2} \mathrm{O}+\mathrm{H}\right]^{+}$, calculated for $\mathrm{C}_{22} \mathrm{H}_{33} \mathrm{O}_{4}\left[\mathrm{M}-\mathrm{H}_{2} \mathrm{O}+\mathrm{H}\right]$ 343.2273. Negative HRESIMS $m / z$ : measured $395.1995[\mathrm{M}+\mathrm{Cl}]^{-}$, calculated for $\mathrm{C}_{22} \mathrm{H}_{32} \mathrm{O}_{4} \mathrm{Cl}[\mathrm{M}+\mathrm{Cl}]$ 395.1989; measured 359.2223 $[\mathrm{M}-\mathrm{H}]^{-}$, calculated for $\mathrm{C}_{22} \mathrm{H}_{31} \mathrm{O}_{4}[\mathrm{M}-\mathrm{H}]$ 359.2222; measured 341.2118 [M- $\left.\mathrm{H}_{2} \mathrm{O}-\mathrm{H}\right]^{-}$, calculated for $\mathrm{C}_{22} \mathrm{H}_{29} \mathrm{O}_{3}\left[\mathrm{M}-\mathrm{H}_{2} \mathrm{O}-\mathrm{H}\right] 341.2117$.

Macrophorin A (3): a pale-colored solid $(\mathrm{MeOH}),[\alpha]_{\mathrm{D}}^{20}+25.7($ c 1.0, $\mathrm{MeOH}),\left([\alpha]_{\mathrm{D}}+29(\mathrm{MeOH})\right.$ in literature [24]). Positive ESIMS m/z: $361[\mathrm{M}+\mathrm{H}]^{+}, 378\left[\mathrm{M}+\mathrm{NH}_{4}\right]^{+}, 383[\mathrm{M}+\mathrm{Na}]^{+}$; negative ESIMS $m / z: 359[\mathrm{M}-\mathrm{H}]^{-}, 395[\mathrm{M}+\mathrm{Cl}]^{-}, 405[\mathrm{M}+\mathrm{HCOO}]^{-}$. IR $v_{\max } \mathrm{cm}^{-1}: 3400,2938.6,2867.8,2844.7$, $1677.4,1458.9,1439.9,1387.8,1365.7,1278.9,1204.3,1103.6,1030.4,882.1,669.1$. CD (2.78 mM, MeOH) $\Delta \varepsilon$ (nm): 0 (389), +2.76 (334), 0 (280), -4.41 (243), 0 (218), +0.31 (215), 0 (212), -1.92 (204). $\mathrm{CD} \lambda_{\max } \mathrm{nm}$ (mdeg) in $\mathrm{MeOH}$ at $1.0 \mathrm{mg} / \mathrm{mL}: 389$ (0), 334 (+25.33), 280 (0), 243 (-40.40), 218 (0), 215 (+2.80), $212(0), 204$ (-17.56). ${ }^{1} \mathrm{H}$ NMR (400 MHz, $\left.\mathrm{CD}_{3} \mathrm{OD}\right) \delta: 5.91\left(1 \mathrm{H}, \mathrm{d}, J=1.6, \mathrm{H}-2^{\prime}\right)$, 4.77 (1H, br s, Ha-12), 4.52 (2H, br s, Hb-12 and H-4'), $4.29\left(1 \mathrm{H}, \mathrm{d}, J=17.7 \mathrm{~Hz}, \mathrm{Ha}-7^{\prime}\right), 4.21(1 \mathrm{H}, \mathrm{d}$, $\left.J=17.7 \mathrm{~Hz}, \mathrm{Hb}-7^{\prime}\right), 3.67\left(1 \mathrm{H}, \mathrm{d}, J=2.9 \mathrm{~Hz}, \mathrm{H}-5^{\prime}\right), 2.33(1 \mathrm{H}, \mathrm{ddd}, J=12.6,3.9,2.5 \mathrm{~Hz}, \mathrm{He}-7), 2.31$ $(1 \mathrm{H}, \mathrm{d}, J=14.0 \mathrm{~Hz}, \mathrm{Ha}-11), 1.92(1 \mathrm{H}, \mathrm{td}, J=12.6,3.9 \mathrm{~Hz}, \mathrm{Ha}-7), 1.81(1 \mathrm{H}, \mathrm{dd}, J=14.0,11.1 \mathrm{~Hz}$, Hb-11), $1.76(1 \mathrm{H}$, dt, calcd $J=12.6,3.9 \mathrm{~Hz}, \mathrm{He}-1$; overlapped with $\mathrm{H}-9$ and $\mathrm{He}-6), 1.75(1 \mathrm{H}, \mathrm{d}$, $J=11.1 \mathrm{~Hz}, \mathrm{H}-9$; overlapped with $\mathrm{He}-1$ and $\mathrm{He}-6), 1.72(1 \mathrm{H}, \mathrm{m}, \mathrm{He}-6$; overlapped with $\mathrm{He}-1$ and $\mathrm{H}-9), 1.60$ (1H, qt, $J=13.6,3.4 \mathrm{~Hz}, \mathrm{H} a-2), 1.49$ (1H, dquint, $J=13.6,3.4 \mathrm{~Hz}, \mathrm{He}-2), 1.38$ (1H, dm, $J=13.6 \mathrm{~Hz}, \mathrm{He}-3), 1.30(1 \mathrm{H}, \mathrm{qd}, J=12.6,3.9 \mathrm{~Hz}, \mathrm{Ha}-6), 1.21(1 \mathrm{H}, \mathrm{td}, J=13.6,4.6 \mathrm{~Hz}, \mathrm{H} a-3), 1.18$ $(1 \mathrm{H}, \mathrm{td}, J=13.6,3.4 \mathrm{~Hz}, \mathrm{Ha}-1), 1.12(1 \mathrm{H}, \mathrm{dd}, J=12.6,2.5 \mathrm{~Hz}, \mathrm{H}-5), 0.70$ (3H, s, H $\left.\mathrm{H}_{3}-13\right), 0.79$ (3H, s, $\left.\mathrm{H}_{3}-14\right), 0.85$ (3H, s, $\left.\mathrm{H}_{3}-15\right) .{ }^{13} \mathrm{C}$ NMR (100 MHz, CD $\left.3 \mathrm{OD}\right) \delta: 195.4$ (C-1'), 161.2 (C-3'), 150.5 (C-8), $120.2\left(\mathrm{C}-2^{\prime}\right), 107.4$ (C-12), 66.2 (C-4'), 62.3 (C-5'), 62.2 (C-7'), 61.2 (C-6'), 56.9 (C-5), 52.9 (C-9), 43.3 (C-3), 40.7 (C-10), 40.0 (C-1), 39.3 (C-7), 34.5 (C-4), 34.1 (C-13), 25.6 (C-6), 22.2 (C-14), 22.0 (C-11), 20.4 (C-2), 15.0 (C-15). The above ${ }^{1} \mathrm{H}$ and ${ }^{13} \mathrm{C}$ NMR data were assigned on the basis of DEPT, ${ }^{1} \mathrm{H}-{ }^{1} \mathrm{H}$ COSY, HMQC, HMBC and NOESY experiments.

\subsection{HPLC Analysis for 1-3 and the G59 and BD-1-6 Extracts}

The EtOAc extracts of G59 and BD-1-6 cultures and the compounds 1-3 were dissolved in $\mathrm{MeOH}$ to prepare a $10 \mathrm{mg} / \mathrm{mL}$ sample solution for HPLC analysis. HPLC analysis of the samples was carried out on a Venusil MP C18 column $(5 \mu \mathrm{m}, 100 \AA, 4.6 \mathrm{~mm} \times 250 \mathrm{~mm}$; Agela Technologies $)$ using the same Waters HPLC equipment mentioned. Each $5 \mu \mathrm{L}$ of sample solutions was injected into the column after filtration by a $0.22 \mu \mathrm{m}$ pore membrane filter. Then, the elution was performed using $\mathrm{MeOH}-\mathrm{H}_{2} \mathrm{O}$ in linear gradient $(20 \% \mathrm{MeOH}$ at initial time $0 \mathrm{~min} \rightarrow 100 \% \mathrm{MeOH}$ at $60 \mathrm{~min} \rightarrow 100 \% \mathrm{MeOH}$ at $90 \mathrm{~min}$; flow rate, $1 \mathrm{~mL} / \mathrm{min}$ ). The acquired photodiode array (PDA) data were processed by Empower PDA software to obtain targeted HPLC data. 


\subsection{LC-ESIMS Analysis for 1-3 and the G59 and BD-1-6 Extracts}

The LC-ESIMS analysis was performed on a LC-MS equipment equipped with Agilent 1100 HPLC system, AB Sciex API 3000 LC-MS/MS system, and AB Sciex Analyst 1.4 software. The above mentioned EtOAc extracts of G59 and BD-1-6, at $10 \mathrm{mg} / \mathrm{mL}$ in $\mathrm{MeOH}$, were employed also for the LC-ESIMS analysis and crude 1-3 samples were used as control. HPLC was carried out on a Venusil MP C18 column $(5 \mu \mathrm{m}, 100 \AA$, $4.6 \mathrm{~mm} \times 250 \mathrm{~mm}$; Agela Technologies $)$ using $\mathrm{MeOH}-\mathrm{H}_{2} \mathrm{O}$ in linear gradient $(20 \% \mathrm{MeOH}$ at initial time $0 \mathrm{~min} \rightarrow 100 \% \mathrm{MeOH}$ at $60 \mathrm{~min} \rightarrow 100 \% \mathrm{MeOH}$ at $90 \mathrm{~min}$; flow rate, $1 \mathrm{~mL} / \mathrm{min}$ ) as mobile phase. The mass detector was set to scan a range from $\mathrm{m} / \mathrm{z} 150$ to 1500 in positive (for 1-3) or negative (for $\mathbf{1}$ ) mode. The acquired data were processed by Analyst 1.4 software to obtain targeted LC-ESIMS data.

\section{Conclusions}

Two new drimenyl cyclohexenone derivatives, purpurogemutantin (1) and purpurogemutantidin (2), and the known macrophorin A (3) were isolated from a mutant BD-1-6 obtained by random DES mutagenesis of a marine-derived fungal strain Penicillium purpurogenum G59. The structures and absolute configurations of $\mathbf{1}$ and $\mathbf{2}$ were determined by extensive spectroscopic methods, especially 2D NMR and ECD analysis. Possible biosynthetic pathways for 1-3 were also proposed and discussed. Compounds 1 and 2 significantly inhibited human cancer K562, HL-60, HeLa, BGC-823 and MCF-7 cells, and 3 also inhibited the K562 and HL-60 cells. Both bioassay and chemical analysis (HPLC and LC-ESIMS) demonstrated that the parent strain G59 did not produce 1-3, and that the DES-induced mutation(s) in BD-1-6 activated some silent biosynthetic pathways in the parent strain G59, including one set for the $\mathbf{1}-\mathbf{3}$ production.

\section{Acknowledgments}

This work was supported by the grants from the National Natural Science Foundation (30973631, 30572279, 30472079, 30171102 and 81172976), the National Science and Technology Major Project (2009ZX09103-019 and 2009ZX09301-002), the National High Technology Research \& Development Program (2007AA09Z411), the Chinese Academy of Sciences (KSCX2-EW-G-6), COMRA (DYXM-115-02-2-09) and AMMS (2008), China. Penicillium purpurogenum G59 was identified by Liangdong Guo, Institute of Microbiology, Chinese Academy of Sciences, China.

\section{References}

1. Geris, R.; Simpson, T.J. Meroterpenoids produced by fungi. Nat. Prod. Rep. 2009, 26, 1063-1094.

2. Swersey, J.C.; Barrows, L.R.; Ireland, C.M. Mamanuthaquinone: An antimicrobial and cytotoxic metabolite of Fasciospongia sp. Tetrahedron Lett. 1991, 32, 6687-6690.

3. Jankam, A.; Somerville, M.J.; Hooper, J.N.A.; Brecknell, D.J.; Suksamrarn, A.; Garson, M.J. Dactylospongiaquinone, a new meroterpenoid from the Australian marine sponge Dactylospongia n. sp. Tetrahedron 2007, 63, 1577-1582. 
4. Yong, K.W.L.; Jankam, A.; Hooper, J.N.A.; Suksamrarn, A.; Garson, M.J. Stereochemical evaluation of sesquiterpene quinones from two sponges of the genus Dactylospongia and the implication for enantioselective processes in marine terpene biosynthesis. Tetrahedron 2008, 64, 6341-6348.

5. Capon, R.J.; Macleod, J.K. A revision of the absolute stereochemistry of ilimaquinone. J. Org. Chem. 1987, 52, 5059-5060.

6. Urban, S.; Capon, R.J. 5-Epi-Isospongiaquinone, a new sesquiterpene/quinone antibiotic from an Australian marine sponge, Spongia hispida. J. Nat. Prod. 1992, 55, 1638-1642.

7. Utkina, N.K.; Denisenko, V.A.; Scholokova, O.V.; Makarchenko, A.E. Determination of the absolute stereochemistry of cyclosmenospongine. J. Nat. Prod. 2003, 66, 1263-1265.

8. Carté, B.; Rose, C.B.; Faulkner, D.J. 5-Epi-Ilimiquinone, a metabolite of the sponge Fenestraspongia sp. J. Org. Chem. 1985, 50, 2785-2787.

9. Ochi, M.; Kotsuki, H.; Muraoka, K.; Tokoroyama, T. The structure of yahazunol, a new sesquiterpene-substituted hydroquinone from the brown seaweed Dictyopteris undulata Okamura. Bull. Chem. Soc. Jpn. 1979, 52, 629-630.

10. Fenical, W.; Sims, J.J. Zonarol and isozonarol, fungitoxic hydroquinones from the brown seaweed Dictyopteris zonarioides. J. Org. Chem. 1973, 38, 2383-2386.

11. Talpir, R.; Rudi, A.; Kashman, Y.; Loya, Y.; Hizi, A. Three new sesquiterpene hydroquinones from marine origin. Tetrahedron 1994, 50, 4179-4184.

12. Kawashima, K.; Nakanishi, K.; Nishikawa, H. Structure of tauranin and a note on the " $\mathrm{C}_{16}$-acids" obtained from di and triterpenoids. Chem. Pharm. Bull. 1964, 12, 796-803.

13. Kawashima, K.; Nakanishi, K.; Tada, M.; Nishikawa, H. Structure of tauranin. Tetrahedron Lett. 1964, 5, 1227-1231.

14. Kono, K.; Tanaka, M.; Ogita, T.; Hosoya, T.; Kohama, T. F-12509A, a new sphingosine kinase inhibitor, produced by a discomycete. J. Antibiot. 2000, 53, 459-466.

15. Wijeratne, E.M.K.; Paranagama, P.A.; Marron, M.T.; Gunatilaka, M.K.; Arnold, A.E.; Gunatilaka, A.A.L. Sesquiterpene quinones and related metabolites from Phyllosticta spinarum, a fungal strain endophytic in Platycladus orientalis of the Sonoran desert. J. Nat. Prod. 2008, 71, $218-222$.

16. Chen, L.; Li, D.H.; Cai, S.X.; Wang, F.P.; Xiao, X.; Gu, Q.Q. A new cytotoxic metabolite from a deep sea derived fungus, Phialocephala sp. Acta Pharm. Sin. 2010, 45, 1275-1278.

17. Ishii, S.; Fujii, M.; Akita, H. First syntheses of (-)-tauranin and antibiotic (-)-BE-40644 based on lipase-catalyzed optical resolution of albicanol. Chem. Pharm. Bull. 2009, 57, 1103-1106.

18. Maezawa, N.; Furuichi, N.; Tsuchikawa, H.; Katsumura, S. Synthesis of a novel sphingosine kinase inhibitor (-)-F-12509A and determination of its absolute configuration. Tetrahedron Lett. 2007, 48, 4865-4867.

19. Poigny, S.; Huor, T.; Guyot, M.; Samadi, M. Synthesis of (-)-hyatellaquinone and revision of absolute configuration of naturally occurring (+)-hyatellaquinone. J. Org. Chem. 1999, 64, 9318-9320.

20. Akita, H.; Nozawa, M.; Shimizu, H. Synthesis of decalin type chiral synthons based on enzymatic functionalisation and their application to the synthesis of (-)-ambrox and (+)-zonarol. Tetrahedron Asymmetry 1998, 9, 1789-1799. 
21. Schröder, J.; Magg, C.; Seifert, K. Total synthesis of the marine sesquiterpene hydroquinones zonarol and isozonarol and the sesquiterpene quinones zonarone and isozonarone. Tetrahedron Lett. 2000, 41, 5469-5473.

22. Laube, T.; Schröder, J.; Stehle, R.; Seifert, K. Total synthesis of yahazunol, zonarone and isozonarone. Tetrahedron 2002, 58, 4299-4309.

23. Toshima, H.; Oikawa, H.; Toyomasu, T.; Sassa, T. Total synthesis of (+)-albicanol and (+)-albicanyl acetate. Biosci. Biotechnol. Biochem. 2001, 65, 1244-1247.

24. Sassa, T.; Yoshikoshi H. New terpene-linked cyclohexenone epoxides, macrophorin A, B and C, produced by the fungus caused Macrophoma fruit rot of apple. Agric. Biol. Chem. 1983, 47, 187-189.

25. Ayer, W.A.; Altena, I.V.; Browne, L.M. Three piperazinediones and a drimane diterpenoid from Penicillium brevi-compactum. Phytochemistry 1990, 29, 1661-1665.

26. Sassa, T.; Nukina, M. Macrophorin D, a new self-growth inhibitor of the causal fungus of Macrophoma fruit rot of apple. Agric. Biol. Chem. 1984, 48, 1923-1925.

27. Fujimoto, H.; Nakamura, E.; Kim, Y.P.; Okuyama, E.; Ishibashi, M.; Sassa, T. Immunomodulatory constituents from an ascomycete, Eupenicillium crustaceum, and revised absolute structure of macrophorin D. J. Nat. Prod. 2001, 64, 1234-1237.

28. Sassa, T.; Ishizaki, A.; Nukina, M.; Ikeda, M.; Sugiyama, T. Isolation and identification of new antifungal macrophorins $\mathrm{E}, \mathrm{F}$ and $\mathrm{G}$ as malonyl meroterpenes from Botryosphaeria berengeriana. Biosci. Biotechnol. Biochem. 1998, 62, 2260-2262.

29. Schmidt, L.E.; Deyrup, S.T.; Baltrusaitis, J.; Swenson, D.C.; Wicklow, D.T.; Goler, J.B. Hymenopsins A and B and a macrophorin analogue from a fungicolous Hymenopsis sp. J. Nat. Prod. 2010, 73, 404-408.

30. Mohamed, I.E.; Gross, H.; Pontius, A.; Kehraus, S.; Krick, A.; Kelter, G.; Maier, A.; Fiebig, H.H.; König, G.M. Epoxyphomalin A and B, prenylated polyketides with potent cytotoxictiy from the marine-derived fungus Phoma sp. Org. Lett. 2009, 11, 5014-5017.

31. Lin, X.; Zhou, X.; Wang, F.; Liu, K.; Yang, B.; Yang, X.; Peng, Y.; Liu, J.; Ren, Z.; Liu, Y. A new cytotoxic sesquiterpene quinone produced by Penicillium sp. F00120 isolated from a deep sea sediment sample. Mar. Drugs 2012, 10, 106-115.

32. Tao, W.; Zhang, Y.; Wang, Y.; Pei, Y. Anti-tumor effects of rubratoxin B on cell toxicity, inhibition of cell proliferation, cytotoxic activity and matrix metalloproteinase-2,9. Toxicol In Vitro 2007, 21, 646-650.

33. King, T.J.; Roberts, J.C.; Thompson, D.J. Studies in mycological chemistry. Part XXX and Last. Isolation and structure of purpuride, a metabolite of Penicillium purpurogenum stoll. J. Chem. Soc. Perkin Trans. 1 1973, 78-80.

34. Tomoda, H.; Nishida, H.; Masuma, R.; Cao, J.; Okuda, S.; Ōmura, S. Purpactins, new inhibitors of acyl-CoA: Cholesterol acyltransferase produced by Penicillium purpurogenum I. Production, isolation and physico-chemical and biological properties. J. Antibiot 1991, 44, 136-143.

35. Nishida, H.; Tomoda, H.; Cao, J.; Okuda, S.; Ōmura, S. Purpactins, new inhibitors of acyl-CoA: Cholesterol acyltransferase produced by Penicillium purpurogenum II. Structure elucidation of purpactins A, B and C. J. Antibiot 1991, 44, 144-151. 
36. de Silva, E.D.; Williams, D.E.; Jayanetti, D.R.; Centko, R.M.; Patrick, B.O.; Wijesundera, R.L.; Andersen, R.J. Dhilirolides A-D, meroterpenoids produced in culture by the fruit-infecting fungus Penicillium purpurogenum collected in Sri Lanka. Org. Lett. 2011, 13, 1174-1177.

37. Tian, C.K.; Cui, C.B.; Han, X.X. Isolation of fungal strains in unusual environment and screening for their antitumor activity. J. Int. Pharm. Res. 2008, 35, 401-405.

38. Brakhage, A.A.; Schroeckh, V. Fungal secondary metabolites-Strategies to activate silent gene clusters. Fungal Genet. Biol. 2011, 48, 15-22.

39. Bode, H.B.; Bethe, B.; Höfs, R.; Zeeck, A. Big effects from small changes: Possible ways to explore nature's chemical diversity. Chembiochem 2002, 3, 619-627.

40. Hosaka, T.; Ohnishi-Kameyama, M.; Muramatsu, H.; Murakami, K.; Tsurumi, Y.; Kodani, S.; Yoshida, M.; Fujie, A.; Ochi, K. Antibacterial discovery in actinomycetes strains with mutations in RNA polymerase or ribosomal protein S12. Nat. Biotechnol. 2009, 27, 462-464.

41. Ochi, K. From microbial differentiation to ribosome engineering. Biosci. Biothenol. Biochem. 2007, 71, 1373-1386.

42. Cichewicz, R.H. Epigenome manipulation as a pathway to new natural product scaffolds and their congeners. Nat. Prod. Rep. 2010, 27, 11-22.

43. Wang, X.; Sena Filho, J.G.; Hoover, A.R.; King, J.B.; Ellis, T.K.; Powell, D.R.; Cichewicz, R.H. Chemical epigenetics alters the secondary metabolite composition of guttate excreted by an atlantic-forest-soil-derived Penicillium citreonigrum. J. Nat. Prod. 2010, 73, 942-948.

44. Chai, Y.J.; Cui, C.B.; Li, C.W.; Wu, C.J.; Tian, C.K.; Hua, W. Activation of the dormant secondary metabolite production by introducing gentamicin-resistance in a marine-derived Penicillium purpurogenum G59. Mar. Drugs 2012, 10, 559-582.

45. Chai, Y.J.; Cui, C.B.; Li, C.W.; Hua, W. Antitumor metabolites newly produced by a gentamicin-resistant mutant of Penicillium purpurogenum G59. J. Int. Pharm. Res. 2011, 38, 216-222.

46. Bringmann, G.; Bruhn, T.; Maksimenka, K.; Hemberger, Y. The assignment of absolute sterostructures through quantum chemical circular dichroism calculations. Eur. J. Org. Chem. 2009, 2009, 2717-2727.

47. Gaussian 09, Revision A.02; Gaussian Inc.: Wallingford, CT, USA, 2009.

48. Snatzk, G. Circular dichroism and absolute conformation: Application of qualitative MO theory to chiroptical phenomena. Angew. Chem. Int. Ed. Engl. 1979, 18, 363-377.

49. Burnett, R.D.; Kirk, D.N. Chiroptical studies. Part 101. An empirical analysis of circular dichroism data for steroidal and related transoid $\alpha, \beta$-unsaturated ketones. J. Chem. Soc. Perkin Trans. 1 1981, 1460-1468.

50. Gawroński, J.K. Circular dichroism and stereochemistry of chiral conjugated cyclohexenones. Tetrahedron 1982, 38, 3-26.

51. Mann, J.; Davidson, R.S.; Hobbs, J.B.; Banthorpe, D.V.; Harborne, J.B. Natural Products: Their Chemistry and Biological Significance, 1st ed.; Addison Wesley Longman Ltd.: Essex, UK, 1996; pp. 289-331.

52. Nabeta, K.; Ichihara, A.; Sakamura, S. Biosynthesis of epoxydon and related compounds by Phyllosticta sp. Agric. Biol. Chem. 1975, 39, 409-413. 
53. Iijima, H.; Ebizuka, Y.; Sankawa, U. Biosynthesis of patulin; in vitro conversion of gentisyl alcohol into patulin by microbial enzyme(s) and retention of one of the carbinol protons in this reaction. Chem. Pharm. Bull. 1986, 34, 3534-3537.

54. Bugni, T.S.; Abbanat, D.; Bernan, V.S.; Maiese, W.M.; Greenstein, M.; van Wagoner, R.M.; Ireland, C.M. Yanuthones: Novel metabolites from a marine isolate of Aspergillus niger. J. Org. Chem. 2000, 65, 7195-7200.

Samples Availability: Available from the authors.

(C) 2012 by the authors; licensee MDPI, Basel, Switzerland. This article is an open access article distributed under the terms and conditions of the Creative Commons Attribution license (http://creativecommons.org/licenses/by/3.0/). 